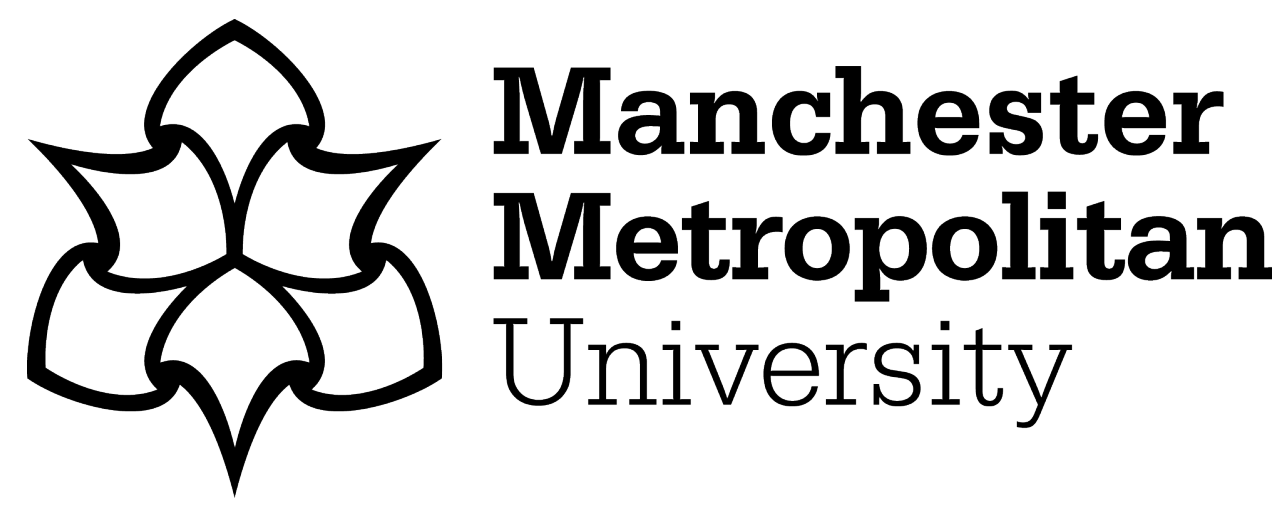

Paucar-Caceres, Alberto ORCID logoORCID: https://orcid.org/0000-00024690-561X, Abuabara, Leila and Toni Burrowes-Cromwell, Toni (2019) Consumers' values and behaviour in the Brazilian coffee-in-capsules market: promoting circular economy. International Journal of Production Research, 57 (23). pp. 7269-7288. ISSN 0020-7543

Downloaded from: https://e-space.mmu.ac.uk/622998/

Version: Accepted Version

Publisher: Taylor \& Francis

DOI: https://doi.org/10.1080/00207543.2019.1629664

Please cite the published version 
Consumers' values and behaviour in the Brazilian coffee-in-capsules market: Promoting circular economy

Leila Abuabara ${ }^{a}$, Alberto Paucar-Caceres ${ }^{b 1}$ and Toni Burrowes-Cromwell ${ }^{b}$

aUniversidade Federal de São Paulo (UNIFESP) - Instituto Tecnológico de Aeronáutica (ITA) - Bolsista CAPES, Praça Marechal Eduardo Gomes, 50 - Vila das Acácias, São José dos Campos, SP, Brazil;

${ }^{b}$ Manchester Metropolitan University Business School, All Saints Campus, Oxford Road, Manchester M15 6BH, UK;

1Email: a.paucar@mmu.ac.uk 


\section{Consumers' values and behaviour in the Brazilian coffee-in-capsules market: Promoting circular economy}

Coffee consumption is changing. Monodose, flavoured coffee capsules provide new experiences beyond the traditional custom of brewing coffee. While these pods mean access to a selection of premium coffee worldwide, they create huge quantities of plastic-aluminium packaging waste. This paper examines the novelty of coffee capsule consumption in Brazil in terms of consumers' perspectives about ethical enterprise and environmental stewardship. We argue for 'waste to resource' management and applying reverse logistics to the coffee production supply chain. Based on Circular Economy principles and fuelled by the 'green' awareness of Brazilian coffee consumers themselves, we propose a conceptual framework to support business decision-making by adopting a systemic intervention from the consumer viewpoint. To structure and scope the problematic situation, we conducted over 40 interviews, using purposive sampling. Analytic Hierarchy Process (AHP), Value Focused Thinking (VFT) and Rich Picture Technique also informed our problem structuring approach. Findings illustrate that the ambition for a reverse supply chain in coffee capsule manufacturing presents real challenges to achieving circular practice. Yet, the ecovalues of Brazilian coffee enthusiasts may be partly considered a 'wealth of information flow' and a potential driving force for change. This paper should be of interest to researchers and practitioners exploring how consumers may contribute to behavioural change, towards more circular business.

Keywords: Supply Chain Management and Brazilian Coffee Industry; Circular Economy; Consumer Green Values; Reverse Logistics; Sustainable Business; Valued-Focused Thinking; Analytic Hierarchy Process; Brazil Coffee- in-Capsules 


\section{Introduction}

The idea that designing enterprise strategy should involve a holistic vision of business is definitely now in vogue (Webster 2015; Harvard Business Review, Feb. 2016; Weetman 2017). It is certainly expressed by the waste to resource goals of circular enterprise, where business profitability is not at the cost of harm to society and the physical environment. Moreover, this vision for a Circular Economy (CE) invites deeper engagement between citizenry and enterprise and, thrives on business social responsibility. It could mean new roles for consumers as both informers and partners for achieving business change and, addressing the so-called 'triple bottom line' (Pollitt 2011; Correia et al. 2017). This paper examines the novelty of Brazil's coffee capsule consumption along these lines of the consumers' perspectives about ethical enterprise.

In recent times, coffee brewing is no longer traditional preparation of a basic beverage. The sophisticated 'coffee-in-capsules' market means a new approach to an individual gourmet experience. Brazilian coffee consumers are now joining this coffee monodose consumption trend. Brazil is the world's largest producer and exporter of coffee and it comes as no surprise that Brazilians are also the world's second largest consumers of coffee. According to the national Coffee Industry Association (Associação Brasileira da Indústria do Café - $A B I C$ ), this translates as $98.2 \%$ of families as coffee drinkers. Although one brand currently holds "monopoly" status as 'customers' choice' (Matzler et al. 2013), there are many other coffee-in-capsules manufacturers entering the market. It is now even possible to manufacture a customized batch of capsules from a specific coffee crop. $A B I C$ statistics indicate this change could mean a per cup price reaching more than six times the cost of the filtered coffee prepared in consumers' homes.

It follows that national coffee companies are investing in their businesses and expanding product ranges to include 'coffee-in-capsules'. Some have described this as the 'third wave' of the coffee industry, focusing on the actual experience of drinking coffee (Silva and Guimarães 2012). This 'third wave' is essentially about the individualization of coffee consumption. It is increasing demand for specialized coffee, different versions of flavours, origins and decaffeination (The European CBI Trends Report 2016; the Brazilian International Report on Coffee Trends/Relatório Internacional de Tendências do Café 2016). These changes are widening the product range beyond established products such as: coffee in granular form, soluble coffee and the original coffee beans. There are also a plethora of coffee shops and production of high quality and value-added coffees in micro-lots which are sold in small packaging sizes (Kashani 2000).

A socio-economic profile of coffee-in-capsule consumption is emerging from this shift to monodose packaging. Firstly, consumers are concentrated in the two main Brazilian metropoles of Sao Paulo and Rio de Janeiro. Secondly, according to IBGE (the Brazilian Institute of Geography and Statistics) these consumer groups may be further categorized by income levels. As a result, conversations are already taking place about the direction of this trend with some ABIC surveys anticipating a considerable increase in coffee consumption (potentially doubling in this contemporary period of 2014 -2019).

This projection has important environmental implications with respect to monodose consumption that is not limited to coffee and, with ambitious potential for other beverages. These include cold/hot teas, juices and sparkling soft drinks as a truly new paradigm of consumption (De 
Chiara in O Estado de S. Paulo, Feb. 2019). The coffee production chain is demanding additional packaging requirements including materials such as aluminium and plastic. Despite much talk about an innovative and promising market, it seems that little has been done about the residue and consequences of this re-styled product (ABIC 2017). Rather, there appears to be a drive to increase profitable coffee capsule sales and marketing, at the expense of responsible production (Folha do Meio Ambiente, Jul. 2016). It is this indiscretion on the part of enterprise which also raises timely questions about the ethical views of coffee consumers and, whether there is opportunity for an industry shift towards more circular business.

We propose that the latter requires acknowledging social capital bound up in the customer/ consumer business exchange (Van Gils et al. 2014; Kanonuhwa and Chimucheka 2014). In this respect, value would be attributed to indigenous knowledge of the customers and their ethical business concerns. In other words, the choices, green values and behaviour of Brazilian coffee consumers are important for a flourishing coffee industry and for Brazil's long-term sustainability goals.

Arguably, some would consider this potential wealth of information flow as 'precious' for future green strategy (Papadopoulos et al. 2010). Romero and Molina (2010) are especially alert to the influence of customer preference on sustainable supply chains. In their discussion about 'Green Virtual Enterprise Breeding Environment', they describe green chain activity as: '. . creating and managing different but integrated flexible forward and reverse supply networks, better known as 'closed-loop supply networks', to address the market dynamic changes and divergent customers' buying behaviour in a sustainable way'. Against this backdrop, this paper's concern is for adoption of more design innovation, 'waste to resource' management and, reverse logistics pertaining to the Brazilian coffee in capsules market. These concepts are rooted in a Circular Economy (CE) approach presented at Figure 1.

We recognize that there are many elements which could determine a company's vote for a sustainable reverse supply chain. Correia et al. (2017) are thorough in exploring this in the context of pursuing industry maturity models. For the purposes of this study, we categorize these broadly as financial and non-financial votes for change. While financial savings are justifiably attractive, among the non-financial reasons for reverse supply chains, we note: environmental and sustainable issues (e.g. recycling, re-use; pursuing value creation through purpose-fit design for upcycling or other recovery of returned products).

It should be stressed that we also acknowledge the importance of appropriate legislation and models for enabling this kind of business change. For example, commercial responsibility (e.g. warranty rights, recalls, exchanges); national legislation or related policy directives may facilitate new measures. These might further undergird product innovation, remanufacturing and pre-owned marketing involving coffee monodose capsules.

This paper has five sections leading on from its introduction. Section 2 starts with the literature review of some concepts used in the proposed framework. In Section 3, we visit the framework, submitting a model for enabling creation of policies and strategies towards collecting coffee capsules and, their subsequent re-introduction in the production cycle. The fourth Section presents the results of the model in practice. In Section 5 we formulate a discussion and recommend 
actions for moving toward circular practices. In the conclusive Section 6, we evaluate the entire process and make some suggestions for future studies.

\section{Literature review of key concepts}

In this section we revise key concepts relevant to the strands of literature underpinning this research. We examine topics such as circular economy (CE) and open and closed loop supply chains (CLSC). Special attention is given to the role of the consumer in helping to bring about change. This potential contribution seems vital to any discussion about economic change and eco-friendly business transition.

General commentary pertaining to the coffee market was topical and relevant for Brazil at the time of writing. The material linking sustainable business to supply chain management provided core sources. These were also a backdrop for (yet emerging) discussion about CE. As a contribution to research design, the literature provided two areas for addressing decision analysis. These are: Value Focused Thinking (VFT) and Analytic Hierarchy Process (AHP). These themes helped to enrich our methodology further detailed in section 3.

\subsection{The Case for a Circular Economy (CE)}

Extant literature is presenting an urgent case for moving from the 'take, use dispose' approach to resources, industry and economics, towards resource circularity and regeneration (Huysman et. al., 2017; Geissdoerfer et.al., 2017; Kalmykova et. al., 2018; Ormazabal et.al, 2018). This concept of a Circular Economy (CE) is fast becoming a global movement. It provides the theoretical framework for the systemic and holistic themes of this study which are further elaborated in Section 3.2. The general idea of $C E$ is to maximize material value for as long as possible in the business supply chain, while minimizing waste. Since the 2015 United Nations General Assembly, the drive to bring about these changes has intensified. So, for example, in the case of this study's food/beverage and packaging theme, sustainable development goal (SDG) 12 stipulates efforts to: '. . . ensure sustainable consumption and production patterns'. ${ }^{2}$

In this regard, circular business acknowledges the finite status of natural resources so vital for sustaining life, the need to preserve ecological harmony and, to ensure sustainable production (Braungart and McDonough 2009, 13). Therefore, this approach demands greater attention to: business resource value, material flows and waste streams. It also implies the need for basic people awareness concerning resource usage for value retention, regeneration or other design innovation (Braungart and McDonough 2009; Romero and Molina 2010; Lacy and Rutqvist 2015; Forlin and Scholz, 2017). It is worth pointing out that basic people awareness within the business arena is not limited to corporations but includes SMEs (Ormazabal, Prieto-Sandoval, Puga-Leal and Jaca, 2018). In

\footnotetext{
${ }^{2}$ See SDG Target 12.3 on Food Loss and Waste: 2018 Progress Report, p.1.
} 
other words, CE shows a distinct regard for creativity and coproduction involving all of business and the rest of society. Put succinctly, it may be defined as 'slow capital' which is inclusive and, poised for the long term.

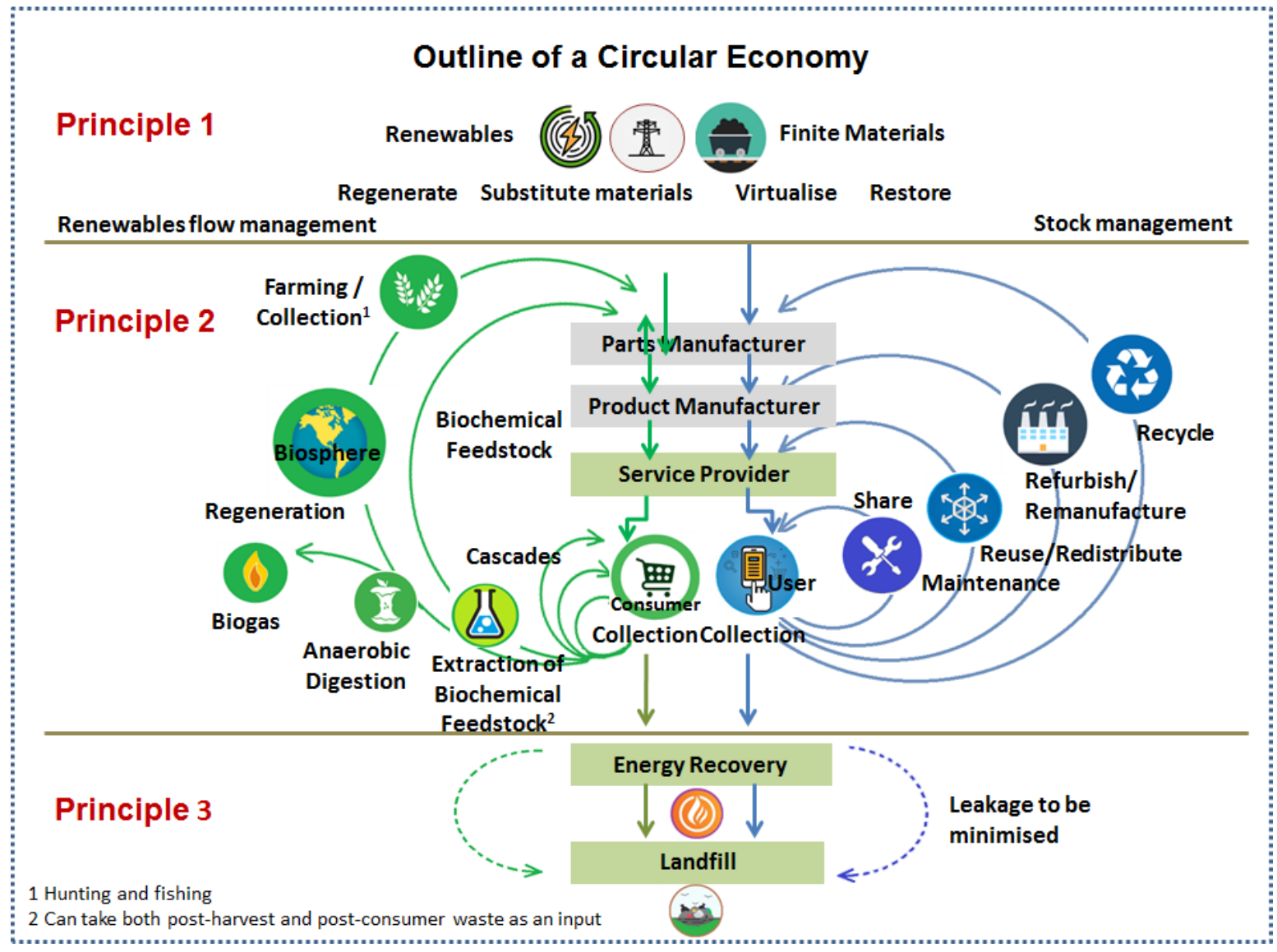

Principles:

(1) Preserve and enhance natural capital by controlling finite stocks and balancing renewable resource flows. ReSOLVE levers: regenerate, virtualize, exchange.

(2) Optimize resource yields by circulating products, components and materials in use at the highest utility at all times in both technical and biological cycles. ReSOLVE levers: regenerate, share, optimise, loop.

(3) Foster system effectiveness by revealing and designing out negative externalities. All ReSOLVE levers.

Figure 1: The Circular Economy 'Butterfly' as outlined by the Ellen MacArthur Foundation, with the support of McKinsey and Company. (Adapted from Webster 2015)

Figure 1 shows the classic systemicity of the CE approach. It is worth noting that in the case of coffee in capsules, both the biological (green) and technical/ finite (blue) parts of the diagram are relevant. In this case, the intent would be to abandon energy and material waste throughout the production process and supply chain of goods and services. This requires weeding out inefficiencies at the design level of these products and services and, closing loops where there are material or other resource losses (Sarkis 2003; Webster 2015). The recent EU 'Monitoring Framework for a 
Circular Economy' (2018:3) outlines four primary areas: (1) production and consumption, (2) waste management, (3) secondary raw materials and (4) competitiveness and innovation.

However, as there is such growing international commitment and experimentation around $\mathrm{CE}$, there may be other categorizations and configurations to this end. For example, within the food industry, product innovations could by-pass the current resource need for external packaging. Clever invention could provide design for edible or biodegradable packaging (See: \#LivingCircular Innovation, 'Icelandic Design: A biodegradable bottle made from seaweed').

With respect to coffee by-products (such as monodose capsules), such new business modelling could be consistent with 'closed loop' goals; designing out negative externalities (such as unnecessary wrapping) and/ or defining biological leftovers and other waste as potential resources. In practical terms, this would allow resource reduction, recovery, redistribution or repurposing of any potential wastage (e.g. foil and plastic from empty coffee capsules). The goal would be to maximize resource energy life, value and use of the materials, throughout the coffee production supply chain (Das and Posinasetti 2015). CE measures would promote production that enhances natural capital (including: crop, soil, water) and balances agricultural and other renewable flows.

However, according to Huysman et. al. (2017: 53) it would be prudent to note issues of compatibility when recycling materials (such as plastic) and to examine what is 'technically feasible'. This suggests the need for some measure of value engineering in assessing appropriate processes, (including transportation) and other factors relating to any by-products or attempts at upcycling. In the case of the Brazilian coffee pod market, dismissing the existing need for plastic and foil wrapping of monodose capsules would still be a significant breakthrough. This is simply because it would be preventing packaging waste.

\subsection{Consumer contribution in moving towards Circular Economy}

Yet, achieving and sustaining a CE is not only about optimising such material gains. It also means involving all the agents representing fundamental parts of the whole process (Linton 2005; Kraaijenhagen, van Oppen, and Bocken 2016). The human cooperative element is paramount and, there are usually three major groupings. These are: consumers, businesses and policy makers (Forlin and Scholz 2017; Chelly et al., 2018) and none of them can work alone effectively (Chen et al. 2012). Whilst distinguishing between 'internal' and 'external collaborators', Forlin and Scholz (2017) also detail the main duties of each agent. We acknowledge this contribution but expand below-starting with the consumer:

(1) Consumers: The consumer's contribution as a stakeholder in promoting responsible business is gaining clearer focus in the literature. Harrison, Newholm and Shaw (2005) readily acknowledge this role. The title of their book proclaims the rise of 'the ethical consumer'. They also stress the need for 'value innovation' that actually addresses compelling customer needs. Esty and Winston (2009) argue that the consumer has in his/her hands the decision 
to throw away or to re-insert the product in the production cycle; while Pollitt (2011) suggests that (in general decarbonization) targets could have collective impact, through more community engagement.

Awareness of user-behaviour is one among seven categories identified by Bressanelli, Perona and Saccani (2018) as being a major challenge for re-designing the supply chain. According to Esposito, Tse and Soufani (2016) in the Harvard Business Review, even with such customer input (post-purchase and use), the entire burden of recycling cannot be placed on the consumer. This is because in any case, the most convenient option would be to throw away used items in the garbage. Within an even more global context (and one step before any consumption), there is a wave of conscious customers who are adopting responsible behavior and looking to buy products that generate minimal carbon emission during the manufacturing and supply processes. This is a growing force and clearly a driver for sustainable products (Chelly et al., 2018).

Therefore, business design which captures consumer viewpoints is critical for both pursuing and sustaining responsible enterprise. This notion hints of some need for circularity in the business information system, with distinct opportunity for information feedback loops. Kraaijenhagen, van Oppen and Bocken candidly summarise: 'Collaboration is necessary in order to innovate for the future' (2016:28). They continue; ' . . . far-reaching collaboration with customers has the potential to lead to 'co-creating' new products or services, quick customer feedback and customer loyalty, which can bring innovation to the organization.' $(2016,28)$.

The point to be made here is that learning new approaches, developing knowledge and exchanging information could represent important 'flow' for achieving circular practice. There is even space to consider a potential hybrid experience in some instances. For example, where the business owner/ employee role merges with that of the consumer (not at all unlikely in view of the national prevalence of coffee drinking in Brazil). Perhaps, this scenario could afford us more integral understanding of social responsibility, without the usual dichotomy between 'business person' and 'customer'

(2) Businesses: The potential for collaboration in this context relates to existing models for reuse, recycling, remanufacturing or upcycling. Here, we specify information, business interests, intentions, capacity and any processes that could support the product's reintroduction. One example of this in another industry is the accepted market for pre-owned cars where we do not simply throw vehicles away. We rely on an already existing business model that will absorb the product and also extend its life cycle. Such model development could mean profitable business surfacing because of market demand or as compliant response to new environmental policies.

At the same time, we appreciate that there is a place for caution here. In her commentary on CE, food and agriculture, Weetman (2017:159) is pragmatic about the coffee sub-sector. She points out: 'Finding new sales channels for by-products may be challenging, especially in 
the early stages when volumes may be erratic and there is little production history to help with the forecasting of supplies. How can you identify the highest value and the most reliable customer channel?'

In this sense and turning inward, fresh perspectives on organizational work practices aiming a final product already originated from a lean and sustainable productive environment can be one route forward. The integration of social and technical aspects on deployment of quality and sustainable management programs can simultaneously improve both business and environmental performance. This positive influence in both areas is noted in Chaudhuri and Jayaram's (2019) research, involving a large multi-country sample. In this same direction, any kind of environmental metrics and criteria that is inclusive of consumers and the general public an environmental quality of the product (e.g, carbon emission index, as referred in Chelly et al., 2018) can state commitment and efforts in this challenge, and, take the business to a better economic performance. However eco-friendly production system or just a cleaner production relays to a product already designed with an environmentally friendly technology, and that is really a great technological challenge for organizations (Govindan \& Hasanagic, 2018).

(3) Policy Makers: Government definitely has an important role to play with regarding enabling circular supply chains, through adequate laws and policies. This positive impulse from national regulators and a multi-perspective framework were recently investigated by Govindan and Hasanagic (2018). This was in their systemic review of content analysis of the most recent literature published between 2000 and 2016. Appropriate legislation and government incentives may provide a critical context for change. These may also facilitate cooperative processes. One example is Brazil's $2^{\text {nd }}$ Edition of the National Policy on Solid Waste (Política Nacional dos Resíduos Sólidos; PNRS 2012). This set of laws advocates shared responsibility of the product life cycle. It also prioritizes the reusable or recyclable packaging for in-country product commercialization. Other policies may address: materials/production bans, tax-reductions, recycling subsidies and, available enterprise training for supporting businesses and consumers.

In view of the above, an 'information resource flow' involving Brazilian coffee capsule consumers (with appropriate business animation and policy context) could help to undergird circular business practice. Consumer buy-in and active participation could be a critical contribution to waste reduction and preventing ongoing material depletion associated with coffee in capsules service. This study makes an important contribution by exploring methods and tools for helping to make such change happen. These efforts are presented in later sections. 


\subsection{The Open and Closed Loop Supply Chain (CLSC)}

The concept of open and closed loop supply chains is pivotal to the above ideals. In systemic terms, it assumes potential for both forward and reverse supply actions and represents ambition for valuing all material and wealth flows. Forward supply chain management (or just supply chain management) refers to the administration of functions, facilities and activities (both within and external to a business organization) that make up a value chain. This involves production and delivery of a product or service and its forward movement in the customer's direction (Stevenson 2009). In illustrating this, Figure 2 shows the destinations of material waste products. In this case, closed-loop is denominated when the returned product is used for products of the same kind; and, open-loop when they feed the manufacturing of other kinds of products (Nakatani 2014).

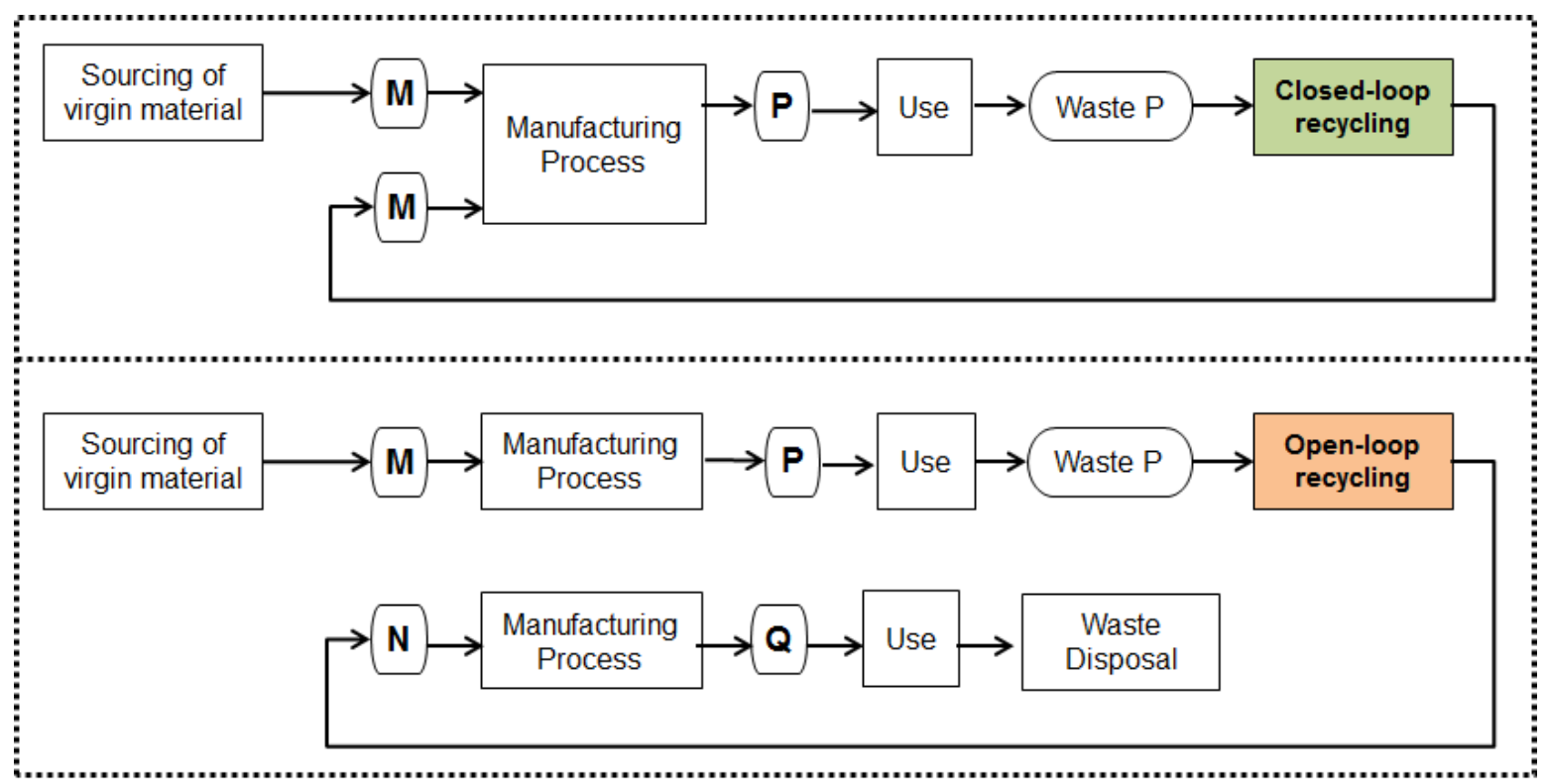

"M": material; "N": recycled material; "P": product; and, "Q": product from recycled material

Figure 2. Closed- and open-loop recycling flows (adapted from Nakatani 2014)

Reverse logistics entails movement in the opposite direction. It includes activity spanning original design and accommodating: (i) value recovery through the re-use of parts as spare-parts or the re-marketing of products as pre-owned; (ii) environmental sustainability through recycle and reuse of a natural resource and; (iii) commercial responsibility due to product return and post-sales services (Das and Posinasetti 2015; Schenkel et al. 2015). Some current examples of this are the 'Take-Back' programs, adopted by the retail-clothing company H\&M, the electronics stores Best Buy; the electronics manufacturer Samsung and; the computer manufacturer Dell (Harvard Business Review, Feb. 2016, Jun. 2016).

In recent years, many approaches and studies have been developed about reverse supply chains. Govindan et al. (2015) offered an overview of these publications (between 2007 and 2013), 
Seuring and Müller (2008) analysed 191 papers published from 1994 to 2007 on sustainable supply chain management and, Rajeev et al (2017) developed a body of knowledge by exploring more than 1000 sustainable supply chain thematic articles published from 2000 and 2015. Bressanelli, Perona and Saccani (2018) categorized 24 CE challenges for supply chain redesign through a systematic literature review and, identified levers that could be used to overcome challenges.

Even the blockchain technology that initially focused on the financial sector (especially digital currency) is now being adopted by sustainable supply chains. Overall, the aim is to create a transparent, traceable, secure and consequently ethical process. This would have advantages for coffee as a part of the food sector. For example, it could help to guarantee product safety, enhance quality and improve sourcing. Of course, there is the obvious advantage of information and materials flow in real time. The obstacles related to implementing this disruptive technology are discussed by Saberi et al. (2019). Notably, their collective analysis is not limited to environmental issues. Legal, technological, social and economic aspects are also taken into consideration.

\subsection{Extracting subjective questions through Value-Focused Thinking (VFT)}

Value-Focused Thinking (VFT) is a creative way to address decision-making problems. It teases out values before giving attention to other aspects of the decision process, including alternative solutions. Developed by Keeney $(1992,1996)$, this approach features development of an 'objectives map' that distinguishes 'means' from 'ends' objectives. These are assessed via cause-andeffect relations of the particular decision context (Franco, Rouwette and Korzilius 2016).

Stakeholders' interviews facilitate individual perceptions and memory about past experiences in similar situations. The resulting 'objectives map' could provide useful guidance for a subsequent process.

According to Schenkel et al. (2015), in a reverse supply chain we can identify value manifestations of four types: economic, environmental, information and customer value. In this article, we use the values identified from VFT methodology to help in the decision-making process. Subsequently, the values identified were transformed as criteria for the Analytic Hierarchy Process (AHP) which is described in the following section.

\subsection{Analytic Hierarchy Process (AHP)}

In most decision processes there is a decision maker who evaluates implicit and explicit criteria. Sometimes there may be minor decisions that are not based on criteria. In other cases, there could be multiple conflicting criteria with alternatives across a range of options, so that a reasonable one can be chosen (Figueira, Greco and Ehrgott 2005). When tackling complex decisionmaking, we can utilize the so-called 'Analytic Hierarchy Process' (AHP). This facilitates setting priorities towards better outcomes. 
Thomas Saaty developed AHP in the 1980s and it has been widely applied to problems in areas such as: economics and planning, energy policy, material handling and purchasing, project selection, supplier selection, budget allocations and forecasting (Goodwin and Wright 2004), robot selection (Goh 1997), quality factor analysis (Bang and Chang 2013) and, managers' selection process (Varajão and Cruz-Cunha 2013), among others. AHP is therefore very popular among decision makers and can be used as stand-alone or integrated with other methods. Emrouznejad and Marra (2017) performed an extensive and in-depth analysis on the body of work on AHP published between 1979 and 2017. This entailed the assessment of 8,441 articles. Their study evidenced the utility and power of AHP by showing it is suited to a number of domains and contexts. By using quantitative analysis, they demonstrated the use of such tools in business and management for the entire evaluated period, with a more recent emergent concern surrounding environmental issues.

We also see many recent applications of this method with 'fuzzy technique' which is a useful tool to deal with imprecise and uncertain data. For example, Chen et al. (2015) evaluated teaching performance and Prakash and Barua (2015) prioritized solutions for reverse logistics with this combined framework. It is not the first time we see AHP being used for the analysis of sustainable issues. There is a variety of articles such as Mathiyazhagan, Govindan and Haq (2014) that explored AHP to identify pressure points for the implementation of green supply chain management (GSCM) in Indian industries. Another selected example is the work of Ghazalli and Murata (2011) that features AHP as a tool for evaluating product end-of-life (EOL) and; Sarkis (2003), where a strategic decision framework is proposed for assisting environmental programs in organizations.

The AHP tool uses a series of 'pairwise' comparisons. According to Emrouznejad \& Marra, (2017), this dynamic relies on the innate human propensity to conduct comparison. In reality, it is also one way of reducing the complexity of a decision. Thus, AHP holds both subjective and objective aspects of any decision (Saaty 1980, 2000). Currently there are some useful and friendly computer packages which were developed to support the application of AHP. Expert Choice (Goodwin and Wright 2004) and Super Decision are examples. AHP could also be explored with Excel spreadsheets (as was the case in this study).

\section{Research framework, design \& methodology}

\subsection{Designing a research framework}

As noted earlier, this article aims to understand how to leverage on the values and behaviour of the coffee-in-capsules consumers (as significant actors in the Brazilian coffee market). Therefore, we utilized interviews and the above problem structuring approaches, for investigating consumer motivation in returning used coffee capsule materials. At its deepest level, the main elements of this framework are based on systemic thinking about business and the rest of society (Checkland, 1981, 1999; Midgley, 2001; McNall, et al., 2015). As a systemic intervention, we incorporated the three dimensions defended by Midgley (2001): (i) philosophy, related to knowledge and revisited concepts; (ii) methodology, in referring to the proposed framework and; (iii) practice, exemplified in this case study. The flowchart at Figure 3 summarizes this study's framework, with details at each stage. 


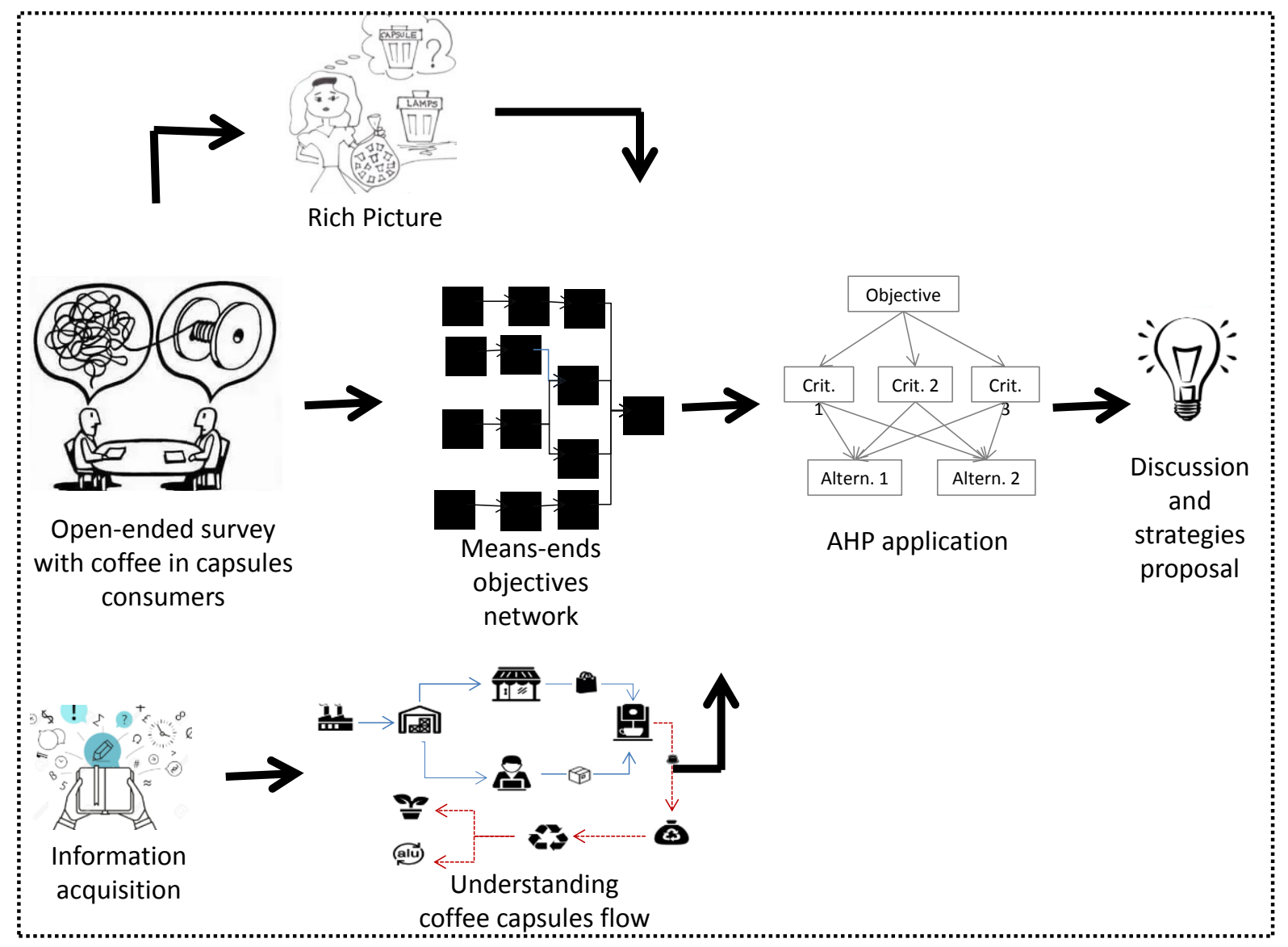

Figure 3. Proposed framework in flow (elaborated by the authors).

Therefore, in terms of 'philosophy', the resounding call of this study's framework is for holism throughout the productive and other business processes. This theme was reflected in the literature on systemic thinking which also helped to determine issues of methodology, the related logistics of waste separation and sustainable supply chains. It is worth noting here that the concept of holism is already intrinsic to CE principles. Hence, it is appropriate as a central motif for the research framework.

Moving beyond these fundamentals, business partnership which involves the consumer (Harrison, Newholm and Shaw, 2005; Pollitt, 2011; Esposito, Tse and Soufani, 2016) is a nascent theme in this study's overall design. Moreover, the aspiration is towards some level of behavioral change at both individual and collective levels (Linton, 2005). In accordance with Midgley's (2001) systemic lenses, these issues relate directly to methodology and to practice.

As a result, we see a spectrum of consumer engagement slowing emerging. For example, we may start with Linton, (2005) who examines the consumer role in the context of civil society. Kanonuhwa and Chimucheka (2014) argue for comprehension and specificity in strategic marketing, whilst Wagner (2013) is very keen for policy change- taking the interesting stance that such inclusion may be considered as a means of extending 'producer responsibility'. Others simply argue for change which addresses the entire business value chain (Kalmykova, Sadagopan and Rosado, 2018). Whatever the case, these approaches collectively complement holism, inclusion and other basic premises of CE. 
The initial literature review helped to define the methodological parameters of the project. As a starting point, it was the basis for outlining a series of open-ended surveys involving coffee in capsules consumers. Unlike a recent British study with coffee in capsules consumers that were contacted using the database of a certain brand (Evening Standard, Feb. 2018), this study used a purposive sample. Initially, respondents were contacted through the authors' network. The intent was for this to expand in 'snowball' fashion, as persons suggested other coffee pod users.

Additionally, basic criteria (detailed further below), required that these persons owned a domestic coffee in capsules machine. Four sequential steps were proposed to guide the enquiry:

(i) Determining whether used capsules were thrown away, if so, the reasons for this.

(ii) Confirming any knowledge of recycling programs promoted by any manufacturers.

(iii) Establishing any interest in participating in coffee pod recycling programs and, noting any perceptions regarding personal risk or inconvenience to the particular consumer.

(iv) Identifying potential incentives for supporting recycling collection (without suggesting specific incentives, so that the person could suggest the most convenient to him/her).

In order to structure and scope the problematic situation, we conducted over 40 interviews, using a purposive sampling approach. Additionally, use of Soft System Methodology, Valued-Focused Thinking and Analytic Hierarchy Process represents a significant contribution, by deliberate application of a suite of systemic tools to help achieve systemic CE outcomes. In short, the empirical part of this research was designed to match the intrinsic complexity of the coffee pod use scenario. Based on the earlier premise that reverse logistics involving coffee capsules would entail some measure of resource recovery and upcycling (e.g. foil, plastics etc.), logistical convenience driven by consumer green values remains at the core of this study (Lin and Ho 2008; Papadopoulos et al. 2010; Kanonuhwa and Chimucheka 2014). This activity might even be interpreted by some as another dimension of collaboration, towards a more closed loop business approach (Linton 2005; Kraaijenhagen, van Oppen and Bocken 2016), along the coffee value chain. Once more, it is consistent with the holism concept.

With reference to Franco and Montibeller (2010), two phases of decision making were defined. Firstly, there was a divergent stage. This entailed: exploring knowledge, learning concepts, understanding local legislation, interviewing stakeholders and, gathering consumer's behavior and green values. During this phase, information and ideas needed to be well established and organized since they would feed the second stage. The latter entailed a convergent focus on strategies and policies that could have evolved into a future database for a decision analysis tool and/ or a strategic action plan for a coffee-in-capsules manufacturer. Figure 4 illustrates the model underpinning the decision-making process for exploring Brazil's current coffee pod consumption. 


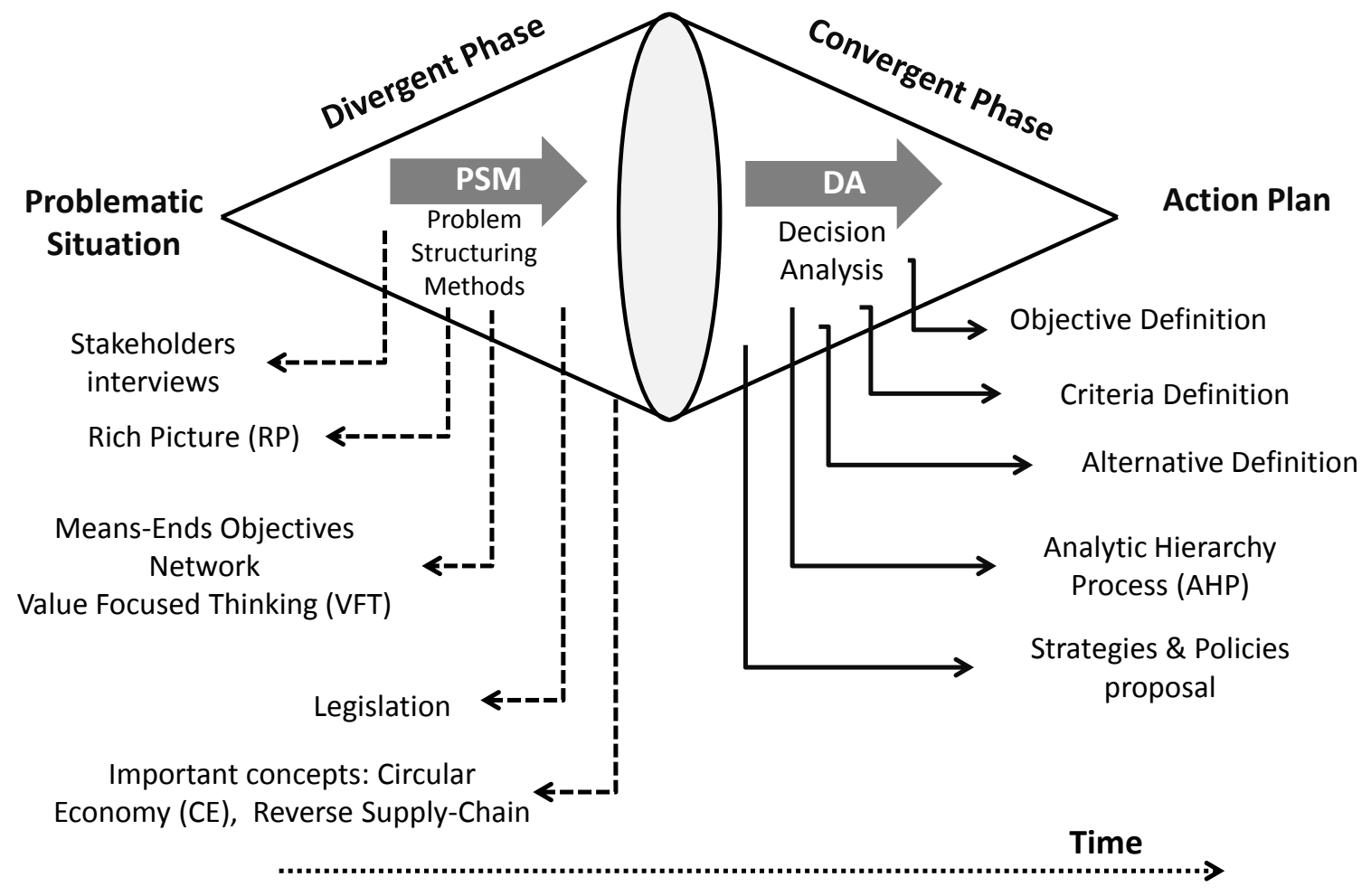

Figure 4. Decision-making process (adapted from Franco and Montibeller 2010)

\subsubsection{Problem Structuring: the divergent phase}

During this phase, we focused on understanding the problematic situation. Stakeholders were contacted for informal interviews. This group included: recyclable material collectors, aluminum recyclers, coffee in capsules manufacturers and coffee in capsules consumers (the latter further detailed at Fig 5). We consulted the information available on manufacturers' websites and on the coffee association reports. We gained understanding surrounding consumers' values through VFT and built a means-ends objectives' network. We also researched Brazilian legislation about consumers and manufacturers' responsibility and, applying circular economy principles to the reverse supply-chain. Overall, we gained useful knowledge to feed into the next stage. This information was applied to drafting criteria and alternatives based on consumers' green values.

\subsubsection{Decision Analysis: the convergent phase}

During this second phase, ideas started to take shape and contributed to the Analytic Hierarchy Process (AHP) (which is also depicted as a mathematical model). Saaty (1980) vouches for AHP as a very powerful tool. It is characterized by a simple way of application so we have not detailed step by step formula and matrix of its process. These are easily found in any AHP reference. Instead, we focus primarily on the application and results discussion. It is worth noting again that the hierarchical structure of AHP (detailing objective, criteria and alternatives) had its foundation in the means-end objectives network of the VFT process (divergent phase). This is an important distinctive of this work's originality. 


\subsection{Understanding the situation: structuring the problematic situation using Soft Systems Methodology (SSM)}

Although widely used in the field of Operational Research, Soft Systems Methodology (SSM) has not been used specifically to explore the complexity of assessing policy making towards circular economy practice. This is a paradox as both SSM and CE share the principle of systemic thinking underpinning their approaches. Yet, we noticed very few papers in the literature making use of these commonality.

However, of note is Adamides et al (2009) who propose a holistic approach to make sense of the ill-structured policy making in solid waste management. This action research was conducted in Greece, using a multi-methodological intervention. The research design included SSM as one of the soft OR methodologies underlining the intervention. Our study also intends to bring to the attention of those working in promoting CE practice, the rich range of soft OR methodologies that can help to promote implementation of CE principles. This is based on the shared key elements of holism, dynamism and emergence. Although applying their ideas mainly to cross sector partnership for community change, McNall et.al. (2015) expand on these triadic features of 'systemic engagement'. Furthermore, in terms of concerted action, they caution that: 'The complexity of messes presents daunting challenges to our collective problem-solving capacities. ..' McNall et.al. (2015:1).

Therefore, in order to investigate the problematic situation of the coffee capsule market, we utilized the 'soft' spectrum of Operational Research Methods. 'Soft' OR also known as Problem Structuring Methods (PSM) include a range of methods (mainly from the Interpretivist camp) that has been gaining ground and popularity among OR practitioners. The Rich Picture (RP) is a simple Soft Systems Methodology (SSM) tool originally developed by Peter Checkland $(1981,1999)$. An RP is useful for opening discussion surrounding individual perceptions towards a broad view about the different issues affecting the situation. Rich pictures are created in a free, unstructured way for capturing participants' interpretation of an actual situation. The development and building of a naïve picture involve steps $1 \& 2$ of the SSM in which the participants describe their understanding of a real-world situation Checkland $(1981,1999)$.

Our initial intention was to propose improvements in the capsules pick-up network through its expansion. This was in order to increase the recycling indices of these items. The data soon revealed that in reality, there was a mismatch with the infrastructure and services that were actually available in Brazil. The existing local networks were not efficient and required support. For example, less than $10 \%$ of Brazilian cities could depend on collection for recycling (IBGE 2010). As a result, we modified our focus and started thinking about policies and strategies that could redirect us to more feasible outcomes.

Figure 5 is our initial Rich Picture in which we attempt to make sense of the situation. It represents the different views of the stakeholders' depiction of the problematic or 'messy' situation. It followed the survey results in describing the realities of managing daily waste. We show three dayto-day situations faced by many coffee-in-capsules consumers committed to environmental protection (characterised as "recycle maniacs"). The upper part of the picture illustrates the consumer without clear information about how s/he should address the used capsules. These were 
accumulated in a bag but there is no indication or known business model as far $\mathrm{s} / \mathrm{he}$ is aware to support any 'pro-green' decision.

The left lower area in this rich picture reflects the fact that media information related to recycling is primarily statistical data from global markets (and not to the Brazilian situation). In effect, it is provision which masks the lack of provision at national or local market levels. The right, lower part of the RP portrays emerging waste to resource innovation by using hundreds of empty capsules for handicraft. This 'upcycling' of former waste is leading to new creations of: jewelry, garlands, toys, home ornaments, among other things.

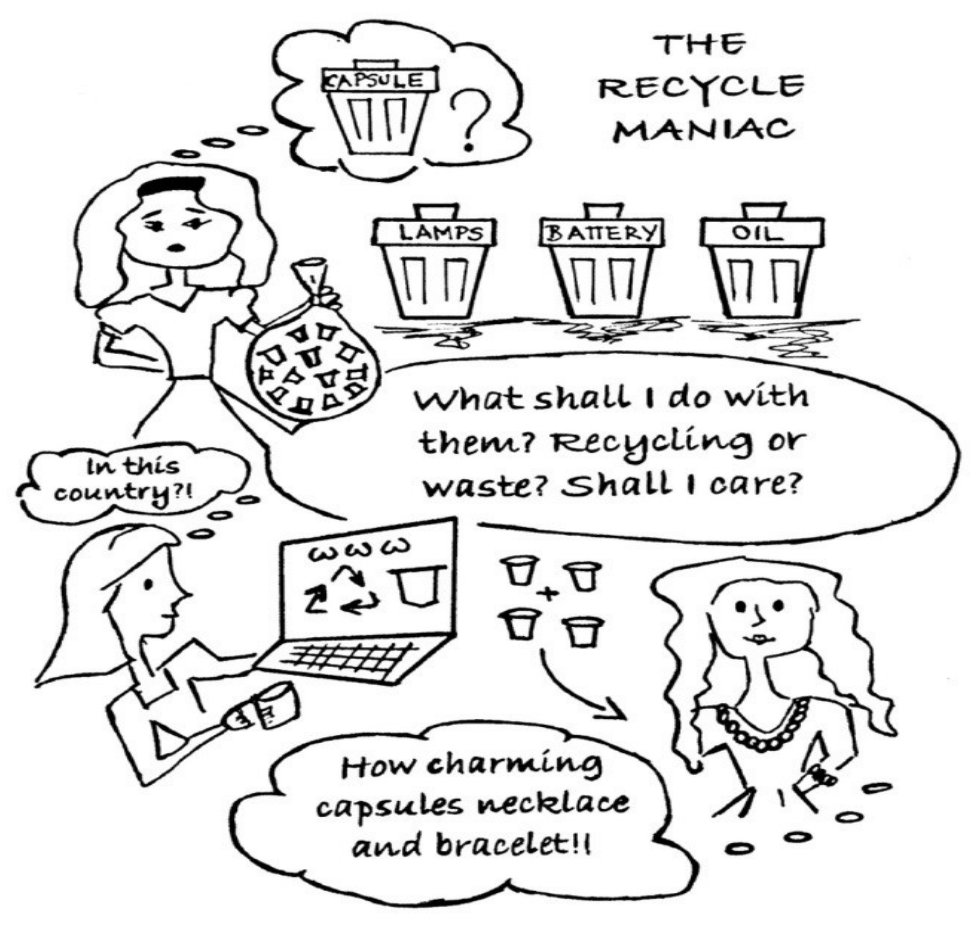

Figure 5. Rich Picture - Managing daily waste (elaborated by the authors).

\section{Circular concepts applied to Brazil's coffee-in-capsules market: Findings and discussion of results}

In this section we report our findings when the CE principles were applied to the Brazilian coffee-incapsules market. We report on interviews conducted and, describe the processes using the decisionmaking of Valued Focused Thinking (VFT) and Analytic Hierarchy Process (AHP). We utilized a means and ends objectives' network for analyzing interview results. This helped us to understand the entire coffee in capsules process from production sourcing to end use, areas of failure and gaps for improvement. Through other research efforts, we built the most likely coffee-in-capsules production flow. Following AHP application, we analysed the results and made suggestions for manufacturers' policies and strategies. 
Our findings show that the overview of coffee in capsules process flow was unclear. Based on the various in-depth conversations and stakeholder information from: coffee in capsules manufacturers (through product support service and website information), aluminium recyclers and consumers, we present Figure 6 below. It illustrates what could be the forward and reverse supplychain of the main coffee-in-capsule distributor in the Brazilian market.

This is a product that is manufactured abroad (1) and exported to Brazil from Europe (despite availability of Brazilian coffee among the options for consumers). There is a centre of storage and distribution (2) located in the São Paulo State where the majority of the consumer market thrives (ABIC 2017). The customer has two ways for coffee-in-capsules acquisition. The first is through the internet store (3) that guarantees delivery anywhere in the country. The second avenue is through dedicated stores called 'boutiques' (4) that are currently presented in a few dozens of locations in the whole country. Time for coffee consumption begins at (5) where we start the dotted line and the reverse route for residual coffee capsule. The customer can return capsules in one of the pick-up points designated by the manufacturer. Arguably, these are a limited number of points, in light of Brazil's vast geographical expanse.

The return through internet option (6) is a recent inclusion in the system (2017). However, it is only available in some regions of São Paulo city (6). Once collected, these coffee capsules represent a sort of hybrid waste, which combines organic and recycled waste (7) and need to be separated in order to meet appropriate waste streams. In this regard, organic material is assigned for composting (8) and aluminium for recycling (9). Since plastic is used by some manufacturers, they would have included plastic as an additional waste material beyond aluminium and the actual coffee.

The recycling facility (7) that is responsible for the process of sorting and disposal of the used capsules is the focal point of the recycling process. In this case, it is a dedicated service and is not provided by a usual recycler. Ideally, this process is one option that could be adopted by a responsible manufacturer committed to improving national 'waste to resource' circular practice. 


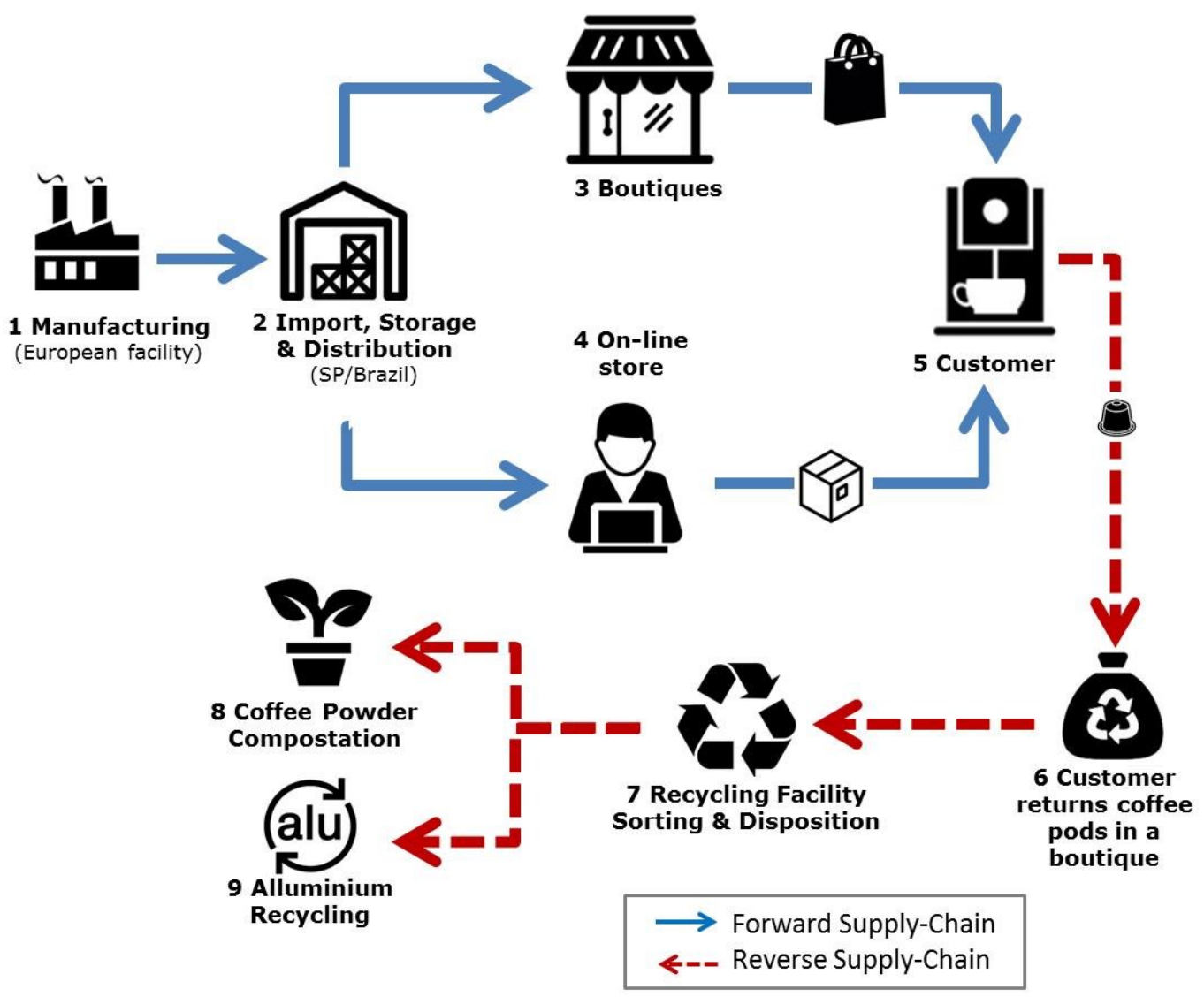

Figure 6. Flow of coffee-in-capsules (elaborated by the authors)

\subsection{Coffee-in-capsules consumers' values, preferences and behaviour}

Forty-five (45) interviews were conducted in order to better understand coffee-in-capsules consumers' values. As mentioned earlier, the only requirement for participating in the interview was domestic ownership of a coffee capsules machine and being a frequent consumer of monodose coffee. The interviewees were mostly concentrated in São Paulo State but not limited to this region. The first ones to be contacted were part of the network known by the authors. Other persons were then suggested for follow up. This information gathering eventually became repetitive, which indicated the end of that data collation phase. Although not a large number of interviewees, the data provided helpful baseline information for this specialized topic of study.

Based on initial findings, we outlined the Means-End Objectives' Network shown in Figure 7. The access to appropriate information and support were critical for awareness of responsible green action. Additionally, there was an emphasis on the lack of waste separation and selective collection in the Brazilian study cities. As mentioned earlier, there are also many creative ideas for use and reuse of the capsules which Brazilians could pursue. These included: handicraft, using any coffee waste as fertilizer and using aluminium/plastics as primary material for other creative processes. 


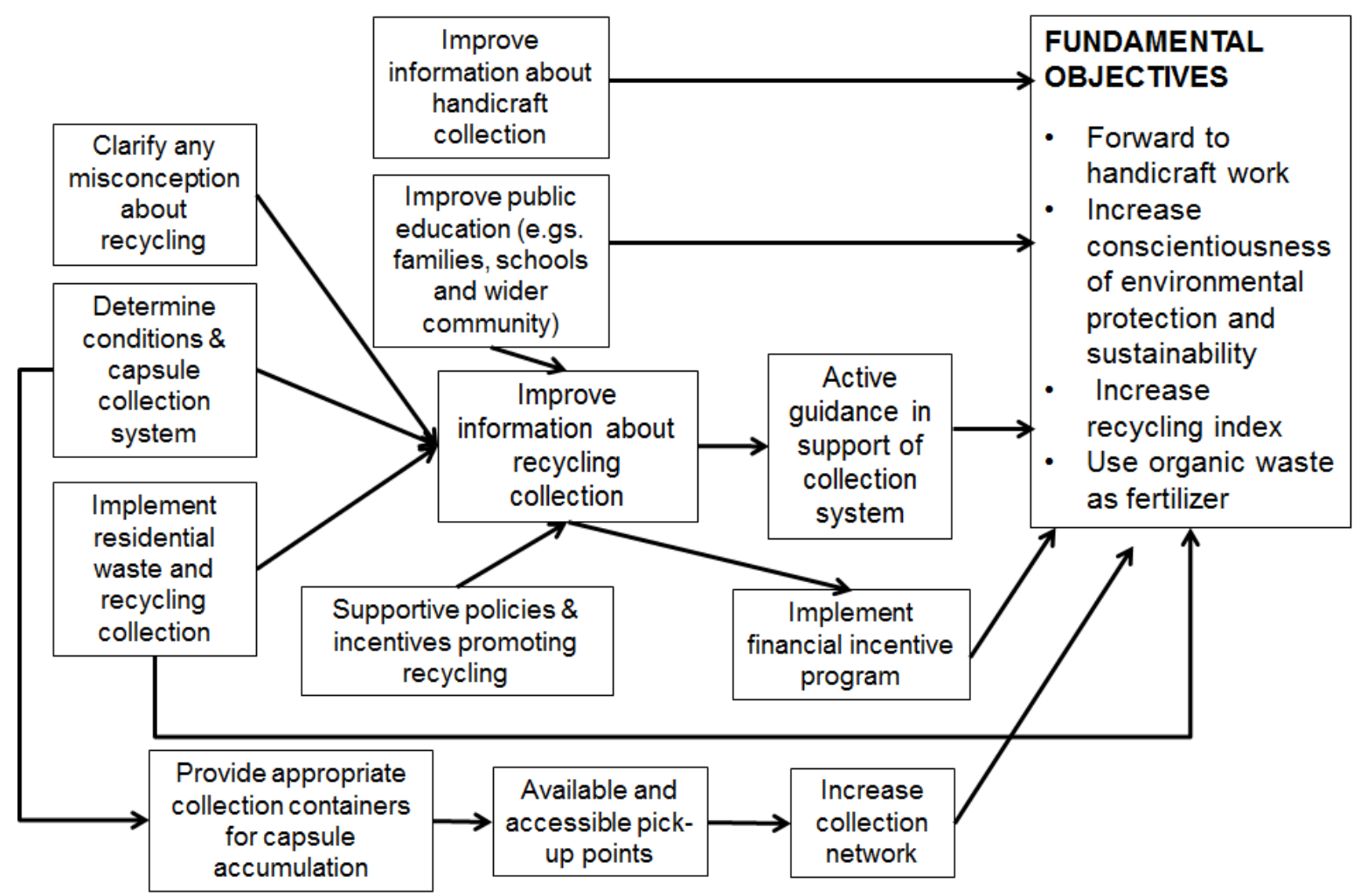

Figure 7. Means-End Objectives' Network (elaborated by the authors)

\subsubsection{Hierarchical information for AHP}

Below, we detail criteria for consumer information gathered through a means-end objectives' network from VFT and, applied by using AHP:

Objective: To investigate actions of coffee-in-capsules consumers, towards promoting circular business practice

\section{Criteria}

- Closeness (geographic accessibility): related to the distance between consumers' home to a pick-up point. We considered a reasonable distance of up to $2 \mathrm{~km}$. For instance, this could mean day-to-day access to a local supermarket, a commercial centre or a public park.

- Earnings: described any financial return (e.g. bonus, discount or prize) for a consumer due to his/her efforts in accumulating the capsules and assigning these to appropriate waste streams.

- Good Deed: acknowledged persons who use capsules as a raw material for handicrafts (e.g. toys and bijouterie), resources/sales arising were being used to support charities or promoting other local social aid.

- Environmental Awareness: concerned any green awareness, which drives consumers' attitudes regarding the environment and sustainability.

- Convenience: related to the ease for a consumer to include waste to resource or other circular efforts, from accumulating and returning capsules in his/her routine. 
Potential Alternatives: The descriptions of alternative actions and respective codes used in the model are presented below:

- Alternative 1: Consumer to take the used capsules to a pick-up point (which may be located more than $2 \mathrm{~km}$ from his/her residence) and receive a bonus for the next purchase. (Code: $\mathrm{PCKPT}+2 \mathrm{~W} / \mathrm{B})$

- Alternative 2: Consumer to take the used capsules to a pick-up point which may be located up to $2 \mathrm{~km}$ from his/her residence. No bonus is foreseen. (Code: PCKPT-2KM)

- Alternative 3: Consumer to accumulate the used capsules and deliver them through the next purchase via internet (domestic collection). A bonus would be received for the next purchase. (Code: RTN.INT_W/B)

- Alternative 4: Consumer to accumulate the used capsules and deliver them through the next purchase via internet (domestic collection). No bonus is foreseen. (Code: RTN.INT)

- Alternative 5: Consumer donates his/her used capsules to a handicraft entity. (Code: DON.CRAFT)

- Alternative 6: Consumer to open used capsules and collect any organic waste for composting. Subsequently, to discard the aluminium in the recycle waste. (Code: COMP.RECY)

Following the hierarchical structure of the decision process proposed by AHP, we constructed Figure 8 below. It shows the relationship across: objective, criteria and alternatives.

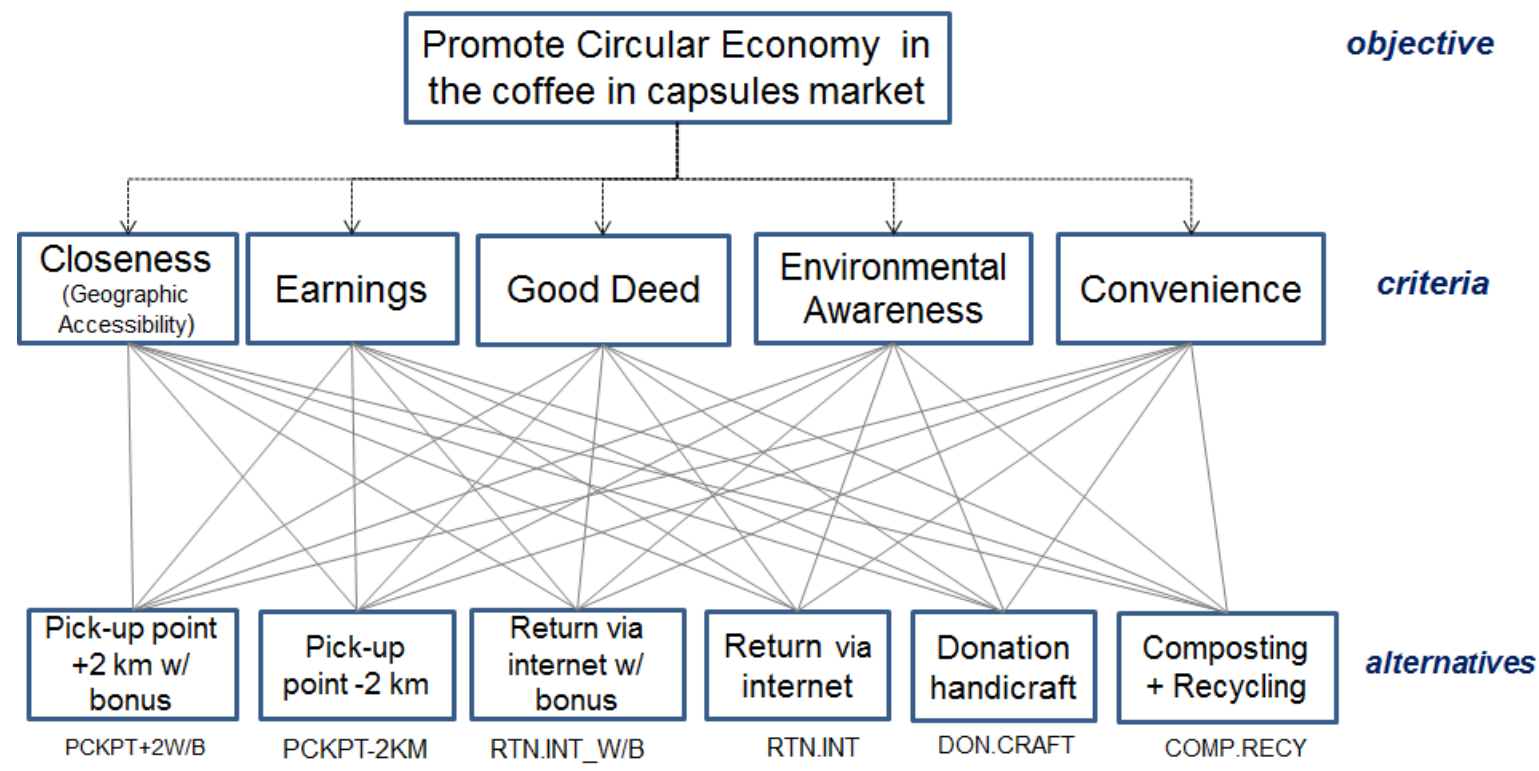

Figure 8. Hierarchical structure of the decision process.

The sequence of matrices of the AHP model application that was gathered from consumers is also presented below. They show opinions in pairwise comparisons. This is a more direct (and less philosophical) way to show their preferences. We start with table 1 which make the pairwise comparison between the objective and the five criteria. 
Followed by the set of tables ( 2 to 6 ) which show the pairwise comparison between each criterion and the six alternatives.

\section{$=$ Table 2 to Table 6 about here=}

Next steps included: normalized pairwise comparison matrices, individual score vectors, score matrix and consistency indexes calculation (which were suppressed for the sake of length of this article). However, the database above may be easily acquired using software mentioned at item 2.3 or Excel spreadsheets. (NB: The authors can provide the remaining matrices upon request).

\section{Discussion, recommended policy/actions for moving towards circular practice in production/marketing coffee-in-capsules}

We present final results of our study below. Table 7 contains the order of alternatives and percentages of the respective preferences expressed by consumers.

\section{=Table 7 about here=}

According to our Analytic Hierarchy Process (AHP) method, coffee manufacturers should make major investment in strategies linked to Alternative 1. However, considering the balanced number of the results, we can say that strategies linked to any of the alternatives would be able to generate some impact in promoting future capsule collection. We note the United Nations 2018 Report on Sustainable Development Goal 12.3 recognizes Brazil's national food loss and waste strategy. However, it also stresses the need for '. . . initiatives involving activities like public private partnerships that span the food supply chain, public policies that support food loss and waste reduction from farm-to-plate, increased investments, farmer and consumer education campaigns. . .$^{3}$ There is opportunity for innovation and further development here.

We list below five main actions that could be adopted in moving towards circular practice, with potential for impact that is consistent with UN 12.3 Champion recommendations:

a) Expansion of urban collecting points, which is currently limited to a small number within the cities under discussion. One likely alternative for achieving this is through partnership with; (i) other companies such as: hypermarkets, shopping malls, gas stations and, post offices frequented by consumers on a weekly basis; (ii) public-private relationship with the municipal administration (Giavannucci and Ponte 2005) in order to erect collecting points in public parks and other strategic points and; (iii) third-party logistics services providers (Rossi et al. 2013; Evangelista et al. 2017) along with the collection of other used products (e.g. batteries,

\footnotetext{
${ }^{3}$ See SDG Target 12.3 on Food Loss and Waste: 2018 Progress Report, p.21.
} 
aluminium cans, etc.). The Harvard Business Review (Jun. 2016) notes these strategies have been adopted by some companies.

b) Including an incentive program to encourage customers to return the capsules or taking them to a pick-up point could mean offering a bonus or a discount for the next purchase or even promotional prizes. Each consumer has a different perception of the significance of recycling. Thus, any form of reward is geared towards encouraging consumer participation in a recycling program. This is also one obvious way to recognize efforts and contribution to the recycling process (Forlin and Scholz 2017). For example, the "Premio Resa", was a financial incentive offered in 2016 by CIAL; the Italian Consortium for the Recovery and Recycling of Aluminium (Consorzio Nazionale per il Recupero e il Riciclo dell'Alluminio) to the Italian waste management companies with recognized performance in aluminium waste separation. These financial gains could be further distributed at the consumer level.

c) Communicate and commit to customers by letting them know about each new pick-up point or increment to the recycling program. This would be with the same measure of fervency with which a new product is advertised or introduced to the market. It is important to update customers about recycling statistics and to emphasise their role in the entire process. Likewise, sharing new recycling achievements and acknowledging mutual contributions are also worthwhile.

d) Nurture a culture of civic responsibility and conscientiousness surrounding waste reduction; sharing these values with customers, while highlighting important linkages involving eco-friendly action, business competitiveness and, sustainable living for everyone. Creative and culturally relevant messaging/campaigning would be a valuable contribution to this strategy. According to Lin and $\mathrm{Ho}(2008)$ the intent to embrace green attitudes is positively linked to green-related knowledge in the first place (even if among other factors). CIAL (3) has a project to promote such awareness especially among secondary school students. The contest is entitled 'Obiettivo Alluminio 2018'. In this case, these teenagers are encouraged to create videos or photo sequences about everyday uses of aluminium: packaging, separate collection, and the importance of recycling. If applied to the coffee monodose capsules, this could be one way to influence young coffee drinkers regarding waste to resource action.

e) Association with specialist recycling companies that master the process of separating the coffee from its capsule in order to exploit each residual separately. One example of this is the crosssector collaboration involving Italian local authorities, private companies, and others with an interest in compost production (e.g. machinery and fertiliser producers). In this case, the Italian Composting and Biogas Association (Consorzio Italiano Compostari - CIC) has been cooperating with a coffee in capsules private company. After a five-year operation they had collected more than 2,000 tons of capsules. Apparently, these numbers increase each year and they reported the use of recycled aluminium in products such as Moka pots and automobiles parts (CIAL 2).

\section{Final remarks and future research}

Drinking coffee using coffee-in-capsules and domestic machines is a novel approach to an old Brazilian custom. Existing commentary about this new way of coffee drinking usually refers to: consumer demand, successful market strategies and product management. This paper locates the 
argument within important discussions about circular economy and the growing green awareness of customers (Lin and Ho 2008; Papadopoulos et al. 2010; Kanonuhwa and Chimucheka 2014). It provides a viable argument for resource preservation and resource recovery within the coffee drinking value chain, based on the commitment of Brazilians to ethical enterprise.

From all indications, the campaign for circular business in Brazil is in an embryonic but hopeful phase. One significant delivery is the recent multi-party initiative to promote CE across Brazil's productive sectors. This 'CE 100' collaboration comprised a network of national stakeholders from construction and agriculture. The latter resulted in a national case study on regenerative agriculture in the sugar industry and, affecting eco-business linked to the Amazon.

Although monodose consumption is increasing, it brings opportunity for including reverse logistics and waste to resource efforts in coffee business agendas and national supply chains. In order to help this transition, this paper, presented a framework combining Problem Structuring Methodologies (PSM) and Decision Analysis (DA) tools. We have proposed a model that suggests policies and strategies for resource recovery from used coffee capsules and their re-introduction into the Brazilian coffee production cycle. In this respect, our model has descriptive and predictive features as it highlights factors affecting consumer participation in recycling programs and the main challenges of current reverse supply chain operations.

Initial use of the Rich Picture technique from Soft System Methodology (SSM) provided some insight into consumer thinking and behaviour. Valued-Focused Thinking (VFT) allowed exploration of consumers' values surrounding environmental stewardship. Criteria (and alternatives) necessary for the application of another decision-making tool: Analytic Hierarchy Process (AHP) were also examined.

Our findings illustrate that the ambition for a reverse supply chain is exposing real challenges to a circular approach to business design. Notably, the narrative about sustainability concepts applied to the Brazilian coffee market is still in evolution. There are drawbacks reflecting emergent properties for attention within the nature and conditions of the industry, supportive waste infrastructure and, the behaviour of customers. Even so, coffee consumers have a critical role to play in helping to turn coffee capsule waste into a resource or supporting other efforts towards circular practice. We argued that the expressed 'green' values of consumers could be a strategic driving force (allowing interaction and feed- back) for this change. This data represents a type of 'information wealth flow' referenced earlier in the study.

This study builds on earlier argument for sustainable coffee production and there are other contributions already giving greater focus to these issues from diverse point of views. For example, Montagna et al. (2017) recently explored technical aspects of the recycling of plastic pods (polymeric waste). Their approach is along the waste to resource goals of this study (although in the same context but from another perspective).

It is worth noting that some conclusions of other studies appear to resonate with our findings. For instance, Wagner (2013) focuses on the concept of convenient collection. He concluded that to increase the amount of waste recovery and maximize consumers' participation, a convenient collection system is vital. Processes under consumers' control such as: segregating waste material (used capsules in our case); storage; transportation to a distant collection site (on or out of 
travelers' way) and; placement in designated areas or containers, require time and effort. As a result, consumers need to be persuaded about the added societal value from these actions, despite their obvious inconveniences. Our findings illustrate that a reverse supply chain in coffee capsule manufacturing presents challenges for circular practice. However, some progress can be made by using Analytic Hierarchy Process (AHP) and exploring a Hierarchical route for defining appropriate policies.

That having been said, we believe that further research is needed. This is especially in revisiting the actual design of the manufactured coffee pods - to exclude the need for current packaging in the first place. We believe this would be even more consistent with CE commitment to design out negative externalities. The result could be edible coffee capsules or (at least) pods with biodegradable capacity. Successful research in this area would completely eradicate the need for discarding coffee capsule waste. Over the long term, it could also be a signature move towards greater consumer satisfaction.

However, for the time being, there may be need for research investment in a new enterprise culture that engages customers in returning empty coffee capsules and, preparatory training in anticipation of a step change. In this case, any new learning and development would support more blended union across the sector divide of: policy decision makers, industry actors and householders. In other words, it would acknowledge the plurality of roles and hybrid status that these actors might experience. This is especially the common reality of either having responsibility for a household or simply living in one.

Although coffee-in-capsules might mean initial financial profits for manufacturers, deeper awareness based on long term and sustainable business strategy is crucial. There may already be lessons to be learned from evolving national business initiatives such as Brazil's CE 100 with the Ellen MacArthur Foundation. Our study argues for business models which include deep and committed customer participation. In making this contribution, we also add business support that employs systemic methodologies and addresses complex human activity, such as waste prevention for the coffee in capsule novelty. We acknowledge that our findings are preliminary and suggest the need for follow up work.

Acknowledgement: The authors are extremely grateful for the constructive comments of the two anonymous reviewers. The first author acknowledges financing from the Coordenação de Aperfeiçoamento de Pessoal de Nível Superior - Brasil (CAPES) - Finance Code 001.

\section{References}

ABIC. 2017. Associação Brasileira da Indústria do Café [Brazilian Coffee Industry Association]. [Online] Available: http://www.abic.com.br/.fil

Bang, W., and Chang, B-Y. 2013. Quality factor analysis of metalworking process with AHP. International Journal of Production Research 51 (19): 5741-5756. doi: 10.1080/00207543.2013.793422. 
Braungart, M., and McDonough, W. 2009. Cradle to Cradle: Rethinking the way we make things. St. Ives UK: Clays Ltd.

Bressanelli, G., Perona, M., and Saccani, N. 2018. Challenges in supply chain redesign for the Circular Economy: a literature review and a multiple case study. International Journal of Production Research. Doi: 10.1080/00207543.2018.1542176.

CBI Trends Report., March, 2016. Coffee in Europe. CBI Ministry of Foreign Affairs. Market Intelligence. The Hague, The Netherlands [Online] Available: https://www.cbi.eu/sites/default/files/market information/researches/trade-statistics-coffee2016.pdf.

CIAL (1). Collection and Recycling of Coffee Capsules. [Online] Available: http://www.cial.it/english post/collection-recycling-coffee-capsules/. [Accessed: $29^{\text {th }}$ March, 2018].

CIAL (2). Italy, the Best Aluminium Waste Separation Performance in 2016 [Online] Available: http://www.cial.it/english_post/premio-resa-2017/. [Accessed: $29^{\text {th }}$ March, 2018].

CIAL (3). Obiettivo Alluminio 2018 - School Contest. [Online] Available: http://www.cial.it/english_post/obiettivo-alluminio-2018/. [Accessed: 29 ${ }^{\text {th }}$ March, 2018].

Chaudhuri, A., and Jayaram, J. 2019. A socio-technical view of performance impact of integrated quality and sustainability strategies. International Journal of Production Research 57(5): 14781496. Doi: 10.1080/00207543.2018.1492162.

Checkland, P.B. 1981, 1999. Systems Thinking, Systems Practice. Chichester, UK: John Wiley and Sons Ltd.

Chelly, A., Nouira, I., Frein, Y., and Hadj-Alouane, A. B. 2018. On The consideration of carbon emissions in modelling-based supply chain literature: the state of the art, relevant features and research gaps. International Journal of Production Research. Doi:

10.1080/00207543.2018.1497310

Chen, J.F., Hsieh, H.N., and Do, Q.H. 2015. Evaluating teaching performance based on fuzzy AHP and comprehensive evaluation approach. Applied Soft Computing 28: 100-108. Doi: 10.1016/j.asoc.2014.11.050.

Chen, C.C., Shih, H.S., Shyur, H.J., and Wu, K.S. 2012. A business strategy selection of green supply chain management via an analytic network process. Computers \& Mathematics with Applications 64 (8): 2544-2557. doi: 10.1016/j.camwa.2012.06.013.

Correia, E., Carvalho, H., Azevedo, S.G., and Govindan, K. 2017. Maturity Models in Supply Chain Sustainability: A Systematic Literature Review. Sustainability 9 (64): 2-26. doi:10.3390/su9010064.

Das, K., and Posinasetti, N.R. 2015. Addressing environmental concerns in closed loop supply chain design and planning. International Journal of Production Economics 163: 34-47. doi: 10.1016/j.ijpe.2015.02.012.

De Chiara, M. (2019). Nas cápsulas, a aposta para a bebida do future. [In the capsules, the bet for the drink of the future]. O Estado de S. Paulo, February 13, 2019. [Online] Available: https://link.estadao.com.br/noticias/inovacao,nas-capsulas-a-aposta-para-a-bebida-dofuturo,70002718886 [Accessed: 30th April, 2019]. 
Descartáveis, a comodidade que não recicla [Disposable, convenience that does not recycle]. Folha do Meio Ambiente, July 05, 2016. [Online] [Accessed: $7^{\text {th }}$ May, 2018] Available:

http://www.folhadomeio.com.br/fma nova/noticia.php?id=3988

Eco-Citizen Design. 2016. Icelandic Design: A biodegradable bottle made from seaweed.

\#LivingCircular, April 9 [Online] Available:

http://www.livingcircular.veolia.com/en/innovations/icelandic-design-biodegradable-bottle-madeseaweed [Accessed: $25^{\text {th }}$ November, 2017].

Edmonds, Lizzie. 2018. Nespresso trials recycling bags just for coffee capsules in affluent Kensington and Chelsea borough. Evening Standard, February 23. [Online] Available:

https://www.standard.co.uk/news/london/nespresso-trials-recycling-bags-just-for-coffeecapsules-in-affluent-kensington-and-chelsea-borough-a3773996.html [Accessed: on 09 May, 2018].

Ellen MacArthur Foundation., 2017. Circular Economy System Diagram. [Online] [Accessed on: November 22, 2017]. Available: https://www.ellenmacarthurfoundation.org/circulareconomy/interactive-diagram

Ellen MacArthur Foundation., 2017. A Circular Economy in Brazil: Case Study Appendix - A product of the collective expertise of the members of the CE 100 Brasil Network. [Online] [Accessed on: May 4, 2017] Available: https://www.ellenmacarthurfoundation.org/assets/downloads/A-CircularEconomy-in-Brazil-Case-Study-Appendix.pdf

Emrouznejad, A., and Marra, M., 2017. The state of the art development of AHP (1979-2017): a literature review with a social network analysis. International Journal of Production Research 55(22): 6653-6675. Doi: 10.1080/00207543.2017.1334976

Esposito, M., Tse, T., and Soufani K. 2016. Companies are Working with Consumers to Reduce Waste. Harvard Business Review. June 7. [Online] Available: https://hbr.org/2016/06/companies-areworking-with-consumers-to-reduce-waste.

EU. 2018. Communication from the Commission to the European Parliament. The Council, the European Economic and Social Committee and the Committe of the Regions on a monitoring Framework for the Circular Economy. COM(2018) 29 final. [Online] Available:

http://ec.europa.eu/environment/circular-economy/pdf/monitoring-framework staff-workingdocument.pdf

Evangelista, P., Colicchia, C., and Creazza, A. 2017. Is environmental sustainability a strategic priority for logistics service providers? Journal of Environmental Management 198:353-362. doi: 10.1016/j.jenvman.2017.04.096.

Figueira, J., Greco, S., and Ehrgott, M. 2005. Multiple Criteria Decision Analysis: State of the art surveys. Kluwer Academic Publishers. [Online] Available:

http://www.springer.com/la/book/9780387230818. doi: 10.1007/978-1-4939-3094-4.

Forlin, V., and Scholz, E.M. 2017. Leveraging consumers' recycling incentives in a Circular Economy. Center for Operations Research and Econometrics. Environmental Economics. 10. [Online] [Accessed on: May 5, 2017]. Available:

https://alfresco.uclouvain.be/alfresco/service/guest/streamDownload/workspace/SpacesStore/3e 0da027-7cea-4a9b-bd03-971bcaa7fa71/coredp2017 10web.pdf?guest=true.

Franco, L.A., and Montibeller, G. 2010. Problem Structuring for Multicriteria Decision Analysis Interventions. Wiley Encyclopedia of Operations Research and Management Science. [Online] Available: 
http://onlinelibrary.wiley.com/doi/10.1002/9780470400531.eorms0683/abstract;jsessionid=DDF5C ADEFC53D6C5721C8F058F9F0C19.f03t01? systemMessage=Wiley+Online+Library+ ed +. doi:

10.1002/9780470400531.eorms0683.

Franco, L.A., Rouwette, E.A.J.A., and Korzilius, H., 2016. Different paths to consensus? The impact of need for closure on model-supported group conflict management. European Journal of Operational Research 249(3): 878-889. doi: 10.1016/j.ejor.2015.06.056.

Geissdoerfer, M., Saveget, P., Bocken, N.M.P., and Jan Hultink, E. 2017. A Circular Economy- A new sustainability paradigm? Journal of Cleaner Production. 143: 757-768.

Ghazalli, Z., and Murata, A., 2011. Development of an AHP-CBR evaluation system for remanufacturing: end-of-life selection strategy. International Journal of Sustainable Engineering. 4(1): 2-15. doi: 10.1080/19397038.2010.528848.

Giovannucci, D., and Ponte S. 2005. Standards as a new form of social contract? Sustainability initiatives in the coffee industry. Food Policy. 30 (3): 284-301. doi: 10.1016/j.foodpol.2005.05.007.

Goh, C.H. 1997. Analytic hierarchy process for robot selection. Journal of Manufacturing Systems. 16 (5): 381-386. doi: 10.1016/S0278-6125(97)88467-1.

Goodwin, P., and Wright, G. 2004. Decision Analysis for Management Judgment. Third edition. Chichester: John Wiley and Sons. ISBN: 978-E-UDT-E0049-2.

Govindan, K., and Hasanagic, M. 2018. A systematic review on drivers, barriers, and practices towards circular economy: a supply chain perspective. International Journal of Production Research 56(1-2): 278-311. Doi: 10.1080/00207543.2017.1402141

Govindan, K., Soleimani, H., and Kannan D. 2015. Reverse logistics and closed-loop supply chain: A comprehensive review to explore the future. European Journal of Operational Research. 240 (3): 603-626. doi: 10.1016/j.ejor.2014.07.012.

Harrison, R., Newholm, T., and Shaw, D. 2005. The Ethical Consumer. (eds). London: Sage Publications. ISBN-10: 141290353X.

Huysman, S., De Schaepmeester, J., Ragaert, K., and De Wulf, J. 2017. Performance indicators for a circular economy: A case study on posti-industrial plastic. Resources, Conservation and Recycling. 120:46-54.

IBGE. 2010. Instituto Brasileiro de Geografia e Estatística. Pesquisa Nacional de Saneamento Básico [Brazilian Institute of Geography and Statistics] [Online] Available: https://ww2.ibge.gov.br/home/estatistica/populacao/condicaodevida/pnsb2008/.

Kalmykova, Y., Sadagopan, M., and Rosado, L. 2018. Circular Economy-From review of theories and practices to development of implementation tools. Resources, Conservation \& Recycling. 135:190201.

Kanonuhwa, M., and Chimucheka, T. 2014. Green Marketing and Purchase Behaviour of Generation $Y$-Consumers. Mediterranean Journal of Social Sciences 5 (20). doi: 10.5901/mjss.2014.v5n20p2785.

Kashani, K. 2000. Innovation and Renovation: The Nespresso Story. Lausanne, IMD Case Study. 
Keeney, R.L. 1992. Value-focused thinking. Cambridge, MA: Harvard University Press. ISBN: 9780674931985.

Keeney, R.L., 1996. Value-focused thinking: Identifying decision opportunities and creating alternatives. European Journal of Operational Research. 92 (3): 537-549. doi: 10.1016/03772217(96)00004-5.

Kraaijenhagen, C., van Oppen, C., and Bocken, N. 2016. Circular Business: Collaborate and Circulate. The Netherlands: Circular Collaboration.

Lacy, P., and Rutqvist, J. 2015. Waste to Wealth: The Circular Economy Advantage. Hampshire, UK: Palgrave Macmillan. doi: 10.1057/9781137530707.

Lin, C.Y., and Ho, Y.H. 2008. An empirical study on logistics service providers' intention to adopt green innovations. J. Technol. Manag. Innov. 3 (1):17-26. ISSN: 0718-2724.

Linton, A., 2005. Partnering for sustainability: business-NGO alliances in the coffee industry. Development in Practice. 15 (3\&4): 600-614. doi: 10.1080/09614520500075664

Mathiyazhagan, K., Govindan K., and Haq A.N. 2014. Pressure analysis for green supply chain management implementation in Indian industries using analytic hierarchy process. International Journal of Production Research, 52 (1): 188-202. doi: 10.1080/00207543.2013.831190.

Matzler, K., Bailom, F., Eichen S.F., and Kohler T., 2013. Business model innovation: coffee triumphs for Nespresso. Journal of Business Strategy. 34(2), 30-37. doi: 10.1108/02756661311310431.

McNall, A., Barnes-Najor, J.V., Brown, R., Doberneck, D., and Fitzgerald, H. 2015. Systemic Engagement: Universities as Partners in Systemic Approaches to Community Change. Journal of Higher Education Outreach and Engagement. 19 (1): 1-27.

Midgley, G., 2001. Systemic Intervention: Philosophy, Methodology and Practice. Kluwer Academic / Plenum Publishers. New York. doi:. /10.1002/casp.702.

Montagna, L.S., Catto, A.L., Oliveira, J.B., Santos, A.M.G. and Santana, R.M.C., 2017. Reciclagem Mecânica de Cápsulas Plásticas de Café [Mechanical Recycling of Plastic Coffee Capsules]. Paper presented at the annual meeting for the 14 Brazilian Congress of Polymers [Congresso Brasileiro de Polímeros - CBPol). Águas de Lindóis (SP). 22-26/Out/2017.

Nakatani, J., 2014. Life cycle inventory analysis of recycling: mathematical and graphical frameworks. Sustainability 6: 6158-6169. doi:10.3390/su6096158.

Ormazabal, M., Prieto-Sandoval, V., Puga-Leal, R., and Jaca, C. 2018. Circular Economy in Spanish SMEs: Challenges and Opportunities. Journal of Cleaner Production. 185:157-167.

Papadopoulos, I., Karagouni, G., Trigkas, M., and Platogianni, E., 2010. Green Marketing- the case of Greece in certified and sustainable managed timber products. EuroMed Journal of business, 5(2): 166-190. doi: 10.1108/14502191011065491.

PNRS. 2012. Política Nacional de Resíduos Sólidos [National Policy on Solid Waste]. 2a Edição, [Online] Available: http://bd.camara.gov.br.

Pollitt, M. 2011. 'Green Values in Communities: How and Why to Engage Individuals with Decarbonization Targets'. In Pitelis, C., Keenan, J., \& Pryce, V. Green Business, Green Values and Sustainability. New York: Routledge. 
Prakash, C., and Barua, M.K. 2015. Integration of AHP-TOPSIS method for prioritizing the solutions of reverse logistics adoption to overcome its barriers under fuzzy environment. Journal of Manufacturing Systems. 37 (3): 599-615. doi: 10.1016/j.jmsy.2015.03.001.

Rajeev, A., Pati, R.K., Padhi, S.S., and and Govindan, K. 2017. Evolution of sustainability in supply chain management: A literature review. Journal of Cleaner Production 162, 299-314. doi: 10.1016/j.jclepro.2017.05.026.

RELATÓRIO INTERNACIONAL DE TENDÊNCIAS DO CAFÉ [Brazilian International Report on Coffee Trends]. 2016. Lavras: Bureau de Inteligência Competitiva do Café. 5(11). [Online] Available: http://www.consorciopesquisacafe.com.br/arquivos/consorcio/publicacoes_tecnicas/Relatorio_v5 _n_11.pdf

Romero, D., and Molina, A. 2010. Green Virtual Enterprises and Their Breeding Environments. A contribution for the ECOLEAD Project (FP6 IP 506958), for the S-MC-S Project (FP7 NMP-ICT-FoF 260090), and for the ITESM, Campus MTY and CCM, Research Chairs.

Rossi, S., Colicchia, C., Cozzolino, A., and Christopher, M. 2013. The logistics service providers in ecoefficiency innovation: an empirical study. Supply Chain Management: An International Journal 18 (6), 583-603. doi: 10.1108/SCM-02-2012-0053.

Saaty, T.L., 2000. Decision making for leaders. Pittsburg, USA:WS. Publications. doi: 10.1109/TSMC.1985.6313384.

Saaty, T.L., 1980. The Analytic Hierarchy Process. New York: McGraw-Hill.

Saberi, S., Kouhizadeh, M., Sarkis, J., and Shen L. 2019. Blockchain technology and its relationships to sustainable supply chain management, International. Journal of Production Research 57(7): 21172135. DOI: 10.1080/00207543.2018.1533261

Sarkis, J., 2003. A strategic decision framework for green supply chain management. Journal of Cleaner Production 11 (4): 397-409. doi: 10.1016/S0959-6526(02)00062-8.

Schenkel, M., Caniëls, M.C.J., Krikke, H., and Laan, E.V.D. 2015. Understanding value creation in closed loop supply chains: Past findings and future directions. Journal of Manufacturing Systems 37 (3): 729-745. doi: 10.1016/j.jmsy.2015.04.009.

Seuring, S., and Müller, M. 2008. From a literature review to a conceptual framework for sustainable supply chain management. Journal of Cleaner Production 16 (15): 1699-1710. doi: 10.1016/j.jclepro.2008.04.020.

Silva, E.C., and Guimarães, E.R. 2012. A 'Terceira Onda' do Consumo de Café [The 'Third Wave' of Coffee Consumption]. Bureau de Inteligência Competitiva do Café. Lavras (MG).

Stevenson, W. J. 2009. Operations Management, 10th edition. McGraw-Hill Irwin.

Tse, T., Esposito, M., and Soufani, K., 2016. How Business Can Support a Circular Economy. Harvard Business Review, February $1^{\text {st }}$. [Online] Available: hbr.org/2016/02/how-businesses-can-support-acircular-economy.

UN. 2018. SDG Target 12.3 on Food Loss and Waste: 2018 Progress Report [Online] Available: https://champions123.org/wpcontent/uploads/2018/09/18 WP Champions ProgressUpdate final.pdf 
Van Gils, A., Dibrell, C., Neubaum, D., and Craig, J. 2014. Social Issues in the Family Business. Family Business Review 27 (3):193-205. doi: 10.1177/0894486514542398.

Varajão, J. and Cruz-Cunha, M.M., 2013. Using AHP and the IPMA Competence Baseline in the project managers selection process. International Journal of Production Research 51 (11): 3342-3354. doi: 10.1080/00207543.2013.774473.

Wagner, T.P. 2013. Examining the concept of convenient collection: An application to extended producer responsibility and product stewardship frameworks. Waste Management 33: 499-507. doi: 10.1016/j.wasman.2012.06.015

Webster, K. 2015. The Circular Economy: A Wealth of Flows. Cowes, UK: Ellen MacArthur Foundation Publishing. ISBN: 9780992778460.

Weetman, C. 2017. A Circular Economy Handbook for Business and Supply Chains: Repair, Remake, Redesign, Rethink. London: Kogan Page Ltd. 
Table 1. Pairwise comparison matrix of the objective and criteria.

\begin{tabular}{|c|c|c|c|c|c|}
\cline { 2 - 6 } \multicolumn{1}{c|}{ Objective } & Closeness & Earnings & Good Deed & Awareness & Convenience \\
\hline Closeness & 1 & 7 & 4 & $1 / 5$ & $1 / 2$ \\
\hline Earnings & $1 / 7$ & 1 & $1 / 3$ & $1 / 7$ & $1 / 7$ \\
\hline Good Deed & $1 / 4$ & 3 & 1 & $1 / 5$ & $1 / 4$ \\
\hline Awareness & 5 & 7 & 5 & 1 & 3 \\
\hline Convenience & 2 & 7 & 4 & $1 / 3$ & 1 \\
\hline
\end{tabular}

Table 2. Pairwise comparison matrix of criterion Closeness and alternatives.

\begin{tabular}{|c|c|c|c|c|c|c|}
\cline { 2 - 7 } \multicolumn{1}{c|}{ Closeness } & PCKPT+2W/B & PCKPT-2KM & RTN.INT_W/B & RTN.INT & DON.CRAFT & COMP.RECY \\
\hline PCKPT+2W/B & 1 & $1 / 5$ & $1 / 8$ & $1 / 8$ & 3 & $1 / 5$ \\
\hline PCKPT-2KM & 5 & 1 & $1 / 5$ & $1 / 5$ & 3 & $1 / 4$ \\
\hline RTN.INT_W/B & 8 & 5 & 1 & $1 / 2$ & 5 & 2 \\
\hline RTN.INT & 8 & 5 & 2 & 1 & 5 & 2 \\
\hline DON.CRAFT & $1 / 3$ & $1 / 3$ & $1 / 5$ & $1 / 5$ & 1 & $1 / 7$ \\
\hline COMP.RECY & 5 & 4 & $1 / 2$ & $1 / 2$ & 7 & 1 \\
\hline
\end{tabular}

Table 3. Pairwise comparison matrix of criterion Earnings and alternatives.

\begin{tabular}{|c|c|c|c|c|c|c|}
\cline { 2 - 7 } \multicolumn{1}{c|}{ Earnings } & PCKPT+2W/B & PCKPT-2KM & RTN.INT_W/B & RTN.INT & DON.CRAFT & COMP.RECY \\
\hline PCKPT+2W/B & 1 & 5 & $1 / 7$ & 5 & 3 & 4 \\
\hline PCKPT-2KM & $1 / 5$ & 1 & $1 / 9$ & 2 & $1 / 2$ & $1 / 3$ \\
\hline RTN.INT_W/B & 7 & 9 & 1 & 9 & 7 & 7 \\
\hline RTN.INT & $1 / 5$ & $1 / 2$ & $1 / 9$ & 1 & $1 / 3$ & $1 / 3$ \\
\hline DON.CRAFT & $1 / 3$ & 2 & $1 / 7$ & 3 & 1 & $1 / 3$ \\
\hline COMP.RECY & $1 / 4$ & 3 & $1 / 7$ & 3 & 3 & 1 \\
\hline
\end{tabular}


Table 4. Pairwise comparison matrix of criterion Good Deed and alternatives.

\begin{tabular}{|c|c|c|c|c|c|c|}
\cline { 2 - 7 } \multicolumn{1}{c|}{ Good Deed } & PCKPT+2W/B & PCKPT-2KM & RTN.INT_W/B & RTN.INT & DON.CRAFT & COMP.RECY \\
\hline PCKPT+2W/B & 1 & $1 / 2$ & 3 & 2 & $1 / 5$ & $1 / 5$ \\
\hline PCKPT-2KM & 2 & 1 & 5 & 3 & $1 / 5$ & $1 / 5$ \\
\hline RTN.INT_W/B & $1 / 3$ & $1 / 5$ & 1 & $1 / 3$ & $1 / 9$ & $1 / 5$ \\
\hline RTN.INT & $1 / 2$ & $1 / 3$ & 3 & 1 & $1 / 7$ & $1 / 3$ \\
\hline DON.CRAFT & 5 & 5 & 9 & 7 & 1 & 5 \\
\hline COMP.RECY & 5 & 5 & 5 & 3 & $1 / 5$ & 1 \\
\hline
\end{tabular}

Table 5. Pairwise comparison matrix of criterion Awareness and alternatives.

\begin{tabular}{|c|c|c|c|c|c|c|}
\cline { 2 - 7 } \multicolumn{1}{c|}{ Awareness } & PCKPT+2W/B & PCKPT-2KM & RTN.INT_W/B & RTN.INT & DON.CRAFT & COMP.RECY \\
\hline PCKPT+2W/B & 1 & 3 & 5 & 5 & 7 & 5 \\
\hline PCKPT-2KM & $1 / 3$ & 1 & 3 & 3 & 3 & $1 / 2$ \\
\hline RTN.INT_W/B & $1 / 5$ & $1 / 3$ & 1 & $1 / 3$ & 3 & $1 / 3$ \\
\hline RTN.INT & $1 / 5$ & $1 / 3$ & 3 & 1 & 3 & $1 / 5$ \\
\hline DON.CRAFT & $1 / 7$ & $1 / 3$ & $1 / 3$ & $1 / 3$ & 1 & $1 / 5$ \\
\hline COMP.RECY & $1 / 5$ & 2 & 3 & 5 & 5 & 1 \\
\hline
\end{tabular}

Table 6. Pairwise comparison matrix of criterion Convenience and alternatives.

\begin{tabular}{|c|c|c|c|c|c|c|}
\cline { 2 - 7 } \multicolumn{1}{c|}{ Convenience } & PCKPT+2W/B & PCKPT-2KM & RTN.INT_W/B & RTN.INT & DON.CRAFT & COMP.RECY \\
\hline PCKPT+2W/B & 1 & $1 / 7$ & $1 / 9$ & $1 / 7$ & $1 / 6$ & 3 \\
\hline PCKPT-2KM & 7 & 1 & $1 / 7$ & $1 / 6$ & $1 / 3$ & 3 \\
\hline RTN.INT_W/B & 9 & 7 & 1 & 5 & 5 & 5 \\
\hline RTN.INT & 7 & 6 & $1 / 5$ & 1 & 3 & 4 \\
\hline DON.CRAFT & 6 & 3 & $1 / 5$ & $1 / 3$ & 1 & 5 \\
\hline COMP.RECY & $1 / 3$ & $1 / 3$ & $1 / 5$ & $1 / 4$ & $1 / 5$ & 1 \\
\hline
\end{tabular}


Table 7. AHP final result.

\begin{tabular}{|c|c|c|c|c|}
\hline Rank & Alternative \# & Code & Result & Alternative description \\
\hline $1^{\text {st }}$ & $\# 1$ & $\mathrm{PCKPT}+2 \mathrm{~W} / \mathrm{B}$ & $23.7 \%$ & $\begin{array}{l}\text { Consumers take the capsules to a } \\
\text { pick-up point more than } 2 \mathrm{~km} \text { from } \\
\text { his/her residence and receive a } \\
\text { bonus for next purchase. }\end{array}$ \\
\hline $2^{\text {nd: }}$ & \#3 & RTN.INT_W/B & $21.0 \%$ & $\begin{array}{l}\text { Consumers accumulate the used } \\
\text { capsules for domestic collection } \\
\text { during the next delivery. A bonus } \\
\text { received for the next purchase. }\end{array}$ \\
\hline $3^{\text {rd }}$ & $\# 6$ & COMP.RECY & $16.9 \%$ & $\begin{array}{l}\text { Consumers open the used capsules } \\
\text { and remove the organic waste for } \\
\text { composting. Subsequently they } \\
\text { discard the aluminium in the recycle } \\
\text { waste. }\end{array}$ \\
\hline $4^{\text {th }}$ & $\# 4$ & RTN.INT & $16.5 \%$ & $\begin{array}{l}\text { Consumers accumulate the used } \\
\text { capsules for domestic collection } \\
\text { during the next delivery. No bonus } \\
\text { foreseen }\end{array}$ \\
\hline $5^{\text {th }}$ & $\# 2$ & РСКРТ-2KM & $12.1 \%$ & $\begin{array}{l}\text { Consumers take the capsules to a } \\
\text { pick-up point up to } 2 \mathrm{~km} \text { from their } \\
\text { residences. No bonus is foreseen }\end{array}$ \\
\hline $6^{\text {th }}$ & \#5 & DON.CRAFT & $9.7 \%$ & $\begin{array}{l}\text { Consumers donate the used } \\
\text { capsules to a handicraft entity. }\end{array}$ \\
\hline
\end{tabular}

